\title{
Understanding consumers' attitudes toward novel food technologies.
}

\author{
Citation for published version (APA):
}

Tenbült, P. (2011). Understanding consumers' attitudes toward novel food technologies. [Doctoral Thesis, Maastricht University]. Maastricht University. https://doi.org/10.26481/dis.20110601pt

Document status and date:

Published: 01/01/2011

DOI:

10.26481/dis.20110601pt

Document Version:

Publisher's PDF, also known as Version of record

\section{Please check the document version of this publication:}

- A submitted manuscript is the version of the article upon submission and before peer-review. There can be important differences between the submitted version and the official published version of record.

People interested in the research are advised to contact the author for the final version of the publication, or visit the DOI to the publisher's website.

- The final author version and the galley proof are versions of the publication after peer review.

- The final published version features the final layout of the paper including the volume, issue and page numbers.

Link to publication

\footnotetext{
General rights rights.

- You may freely distribute the URL identifying the publication in the public portal. please follow below link for the End User Agreement:

www.umlib.nl/taverne-license

Take down policy

If you believe that this document breaches copyright please contact us at:

repository@maastrichtuniversity.nl

providing details and we will investigate your claim.
}

Copyright and moral rights for the publications made accessible in the public portal are retained by the authors and/or other copyright owners and it is a condition of accessing publications that users recognise and abide by the legal requirements associated with these

- Users may download and print one copy of any publication from the public portal for the purpose of private study or research.

- You may not further distribute the material or use it for any profit-making activity or commercial gain

If the publication is distributed under the terms of Article $25 \mathrm{fa}$ of the Dutch Copyright Act, indicated by the "Taverne" license above, 
Understanding consumers' attitudes toward novel food technologies 
Colophon

Lay-out: PMA Tenbült

Cover: Drukkerij Coppelmans, Eersel

Production: Drukkerij Coppelmans, Eersel

Copyright (C) 2011 PMA Tenbült, Eersel

All rights reserved

ISBN: 978-90-77713-31-0

This research was supported by a grant from ZonMw (014-12-001) 


\title{
Understanding consumers' attitudes toward novel food technologies
}

\author{
Proefschrift
}

ter verkrijging van de graad van doctor aan de Universiteit Maastricht, op gezag van de Rector Magnificus, prof. mr. G.P.M.F. Mols volgens het besluit van het College van Decanen, in het openbaar te verdedigen op woensdag 1 juni 2011 om 14.00 uur door

Petronella Maria Aloysia Tenbült 


\section{Promotor}

Prof. dr. N. K. de Vries

Copromotor

Dr. C. Martijn

Beoordelingscommissie

Prof. dr. G. J. Kok (voorzitter)

Prof. dr. H. W. van den Borne

Prof. dr. L. Frewer

Prof. dr. J. van der Pligt

Dr. S. P. J. Kremers 


\section{Contents}

Chapter $1 \quad$ General introduction 7

Chapter 2 Intuitive and explicit reactions towards "new" food technologies: Attitude strength and familiarity

Chapter 3 Categorizing genetically modified food products:

Effects of labelling on information processing

Chapter $4 \quad$ Evaluating food products: The relation between evaluation strategies and attitude strength

Chapter 5 Acceptance of genetically modified foods:

The relation between technology and evaluation

Chapter $6 \quad$ General Discussion

Summary

69

Nederlandse samenvatting

References

Dankwoord 

Chapter 1

General introduction 
New food products are the lifeblood of food companies (Fuller, 2004). Therefore, the introduction of new food products is critical to both manufacturers and retailers (Gellynck, Vermeire, \& Viaene, 2007). In order to meet constantly changing consumer demands for new food products, manufacturers and retailers attract new customers and increase profits, sales and market share. The modern consumer may choose between a diversity of 'new' foods. Tuorila (2001) divided these new foods into categories of functional foods (of which health effects are clinically demonstrated), nutritionally modified foods (with for example more fiber or less fat), organically produced foods (produced in traditional farming conditions without fertilizers or pesticides), genetically modified foods (produced using gene technology) and ethnic foods (unfamiliar here, but known somewhere else). These new food products are continuously launched in the market but only a few of them will survive for a long period on the retail shelves since more than sixty percent of the new products in the food and drinks industry are reputed to fail in their first year (Costa \& Jongen, 2006; Grunert \& Valli, 2001; Traill \& Grunert, 1997). Consumer acceptance is crucial for the development of successful food products and therefore the understanding of how consumers perceive and form attitudes towards new food technologies is of utmost importance for the food industry (Nielsen et al., 2009; MacFie, 2007) and policy-makers (Rollin, Kennedy, \& Wills, 2011). Since public acceptance towards many food technologies is still an open question (De Barcellos et al., 2010), investigating the origins of people's evaluations of new food technologies can create insight into how these evaluations are formed and how they are influenced.

The present dissertation focuses on the evaluation of food innovations. A series of studies will be reported to understand the structural features and process variables associated with the perception and evaluation of modern food technologies. For this dissertation we chose food categories that represent relatively well-known food technologies (vegetarian foods and organic production) and relatively recent food innovations (genetic modification, food supplements and functional foods).

In the current chapter, a brief overview of the theoretical background will be provided. In order to understand how food evaluations are constructed it is important to get insight into how associative networks function and how information is derived from memory. This chapter will conclude with an overview of the remaining chapters of this dissertation.

\section{Associations}

Evaluations are based on associations that people have with an object, in this case food products. Not all foods have the same associations, and not all associations will automatically come to mind when confronted with a certain product. Therefore some understanding of associative memory is needed to understand the way evaluations are formed.

According to modern cognitive theory (Sternberg, 1996), innumerable concepts are interconnected with each other in a network in memory. These concepts may represent all kind of things, for instance concepts ('fruits'), objects ('apple'), attributes ('green') or evaluations ('nice'). The network consists of a huge and complex web of connections between nodes that represent these concepts (e.g. the concept 'fruit' is connected to 'apple'). Nodes become activated, for instance, when a person is confronted with a stimulus or is actively thinking about a concept. When the activation of a node is above a certain threshold, the concept comes to mind. Association is conceived to be a process of activation spreading to nodes that are related (i.e. connected) to the activated node. The connections 
between nodes differ in strength (e.g. the concept 'fruit' has a stronger connection to 'apple' than to 'mango'). Depending on the strength of different connections, activation will spread to other nodes. The more often a certain connection is activated, the greater the strength of the connection will become (Sternberg, 1996). For example, suppose you cannot remember the brand of the apple you ate yesterday. First the concept 'apple' becomes activated. Consequently, concepts that are associated with the concept apple, like concepts that represent brand names, become activated due to spreading activation. It could be that the activation of the concept that represents the right answer (e.g. Red Delicious) does not pass threshold value: it does not come to mind. When additionally the concept 'red' is activated (because you remember that the apple had a red color), the concept of 'Red Delicious' becomes additionally activated because it is associated with both the concepts 'apple' and 'red'. This might be enough to bring the name 'Red Delicious' to mind.

\section{Hierarchies and automatic and analytical processes}

Within a network, concepts are hierarchically organized. The most concrete concepts are at the bottom, and more abstract concepts are at higher levels. For example, the concept 'fruit' is at a high, superordinate level. At a lower level different categories of fruits are present, for example 'tropical fruits' and 'temperate fruits' and at the lowest, subordinate level exemplars are represented (respectively 'avocado' and 'apple') (Kunda, 1999; Rosch, Mervis, Gray, Johnson, \& Boyes-Braem, 1976).

Whatever is known about items at a higher level can be inferred to all items at lower levels in the hierarchy. The inference of information is an automatic, non-analytical, relatively unconscious process (Garcia-Marques \& Mackie, 2001). In automatic processing more abstract and general knowledge and evaluations is inferred from general knowledge (from the superordinate level) to judge objects (Grunert, Bredahl, \& Scholderer, 2003). Thus when you believe that fruit is healthy, an apple and a kiwi must also be healthy because they both are fruits. Before information can be inferred automatically, the higher order knowledge has to be inductively constructed: information has to be generalized analytically from exemplars. When you have analyzed that an apple is healthy, that a banana is healthy and a pear is healthy, this information can be generalized into the idea that all fruits are healthy. This higher level information can then be used when you encounter other types of fruit. When an object is subsequently categorized as a fruit, it can be inferred that it is healthy. In contrast, analytic processing involves careful attention to the specifics of the situation or the object and is a relatively conscious process (Grunert et al., 2003). Analytical processing requires attention and therefore occurs when someone is both willing and able to perform the task at hand (Kunda, 1999). Conversely, in situations where motivation or cognitive ability is inhibited, it is harder for a person to process information analytically. In this case, information has to be processed automatically.

\section{Evaluating a new category}

People activate different aspects of their mental representations of objects depending on which aspects are relevant (Sia, Lord, Blessum, Thomas, \& Lepper, 1999). For example, when people have to mention characteristics of an avocado, people automatically activate the concept fruit and consequently all categories of fruit (for example 'tropical fruits' and 'temperate fruits') get slightly activated too, due to spreading activation. When the avocado is classified as an exemplar of the category 'tropical fruit', this category gets activated (temporarily) above threshold and the needed information can be inferred (e.g. grows in 
warm countries). When the avocado was (falsely) classified as belonging to the category 'temperate fruit' other information would be inferred instead. Thus, whether a concept is labelled as belonging to a certain category or another has consequences for what information gets inferred and consequently how it is perceived.

As mentioned above, higher levels in the hierarchy contain abstract concepts. These abstract general judgments contain beliefs that often cannot be verified or tasted by the consumer (e.g. I believe that this product is healthy, safe or natural). These abstract, nonverifiable, general judgments are called credence attributes (Steenkamp, 1989). It can be assumed that people infer a credence attribute automatically when categorizing familiar products and will then apply this criterion to the stimulus products in order to categorize them. In contrast, Garcia-Marques and Mackie (2001) showed that when situations are new, analytic strategies are triggered. When people have little experience with a 'new' category of objects, they have not yet made generalizations at a higher level. So, when confronted with a new object of such a category, it is hard to make inferences about this object. In this case people will search actively for information to base their evaluation (attitude) on.

It can be assumed that people have difficulty with judging novel products, because a category that represents these products is not readily available. Consequently, they cannot infer information automatically. Therefore it is plausible that people will use an analytic processing strategy when confronted with novel products and will search at the concrete level in the hierarchy for criteria to base their evaluation on. It can be assumed that the generalized information from the exemplars are concrete judgments. In contrast with nonverifiable criteria, concrete judgments can be verified by the consumer and therefore we will refer to these criteria as verifiable criteria (Steenkamp, 1989). Verifiable criteria concern the physical characteristics of a stimulus or one's own reactions at the stimulus that can be empirically observed, for example, these products are vegetables or this product tastes bitter. Both strategies help consumers to form attitudes towards products.

\section{Attitudes}

An attitude in the definition of Eagly and Chaiken is: "the psychological tendency to evaluate a particular entity with some degree of favour or disfavour" (1993, p.1). Thus, attitudes can be seen as evaluations of objects (e.g. persons, situations, ideas, etcetera) which can range from very negative to very positive. For example, you can have a very negative attitude towards lying, a positive attitude towards your neighbour and a very positive attitude towards roses. Attitudes are supposed to be related to cognitions, affective reactions and behavioural tendencies (intentions and actual conduct): a positive evaluation leads to approach tendencies, a negative evaluation to avoidance. The extent to which attitudes predict behaviour varies and depends among other factors on the strength of the attitude. For example, when you have a very strong positive attitude towards blood donation, you are likely to actually donate blood. Strong attitudes are stable over time, less susceptible to context effects and more predictive of behaviour. In contrast, weak attitudes are constructed on the spot, subject to change and less strongly related to accompanying behaviour (Holland, Verplanken, \& van Knippenberg, 2002).

The strength of an attitude depends on its position on two dimensions; centrality and commitment. Centrality refers to the strength of the link between an attitude and characteristics of the self ('how important is this for me'). Centrality is an aspect of the inter-attitudinal structure of an attitude: it reflects the intensity of associations with other elements in the cognitive structure (e.g., other attitudes, values, personality traits, goals). 
Commitment refers to the accessibility of the link between an attitude object and its evaluation ('how convinced am I about my opinion'). It is an aspect of the intra-attitudinal structure of an attitude because it is related to structural properties of the attitude itself (e.g., behavioral, cognitive or affective evaluations). Although centrality and commitment are moderately correlated, they are conceptually distinct. For example, people can find certain issues (e.g., death penalty, nuclear power, genetic modification) very important, but are uncertain of whether they are in favor or against (Holland, 2003).

Holland showed that highly central attitudes are strongly embedded in the cognitive structure of the personal self. They are, therefore, more predictive of behavior than less central attitudes. When people have highly committed attitudes, they can make decisions concerning these attitude issues without much deliberation (relatively automatically). These attitudes can easily be retrieved from memory, are held with great confidence and are therefore not easily affected by context. By measuring people's attitude centrality and commitment, one can investigate whether attitudes are well embedded and accessible.

\section{Measuring attitudes}

A problem with measuring explicit attitudes is that verbal reports depend on conscious introspection, by eliciting verbal responses to statements about feelings, beliefs and behaviour (Fazio \& Olson, 2003; Ottaway, Hayden, \& Oakes, 2001). Not all attitudes can be validly measured with explicit measurements, for example when attitudes are not readily accessible or when it concerns issues that are relatively unknown. Some food technologies, like genetic engineering, are relatively new and consumer knowledge about this technology is limited (Cuite, Aquino, \& Hallman, 2005; House, Lusk, Jaeger, Traill, Moore, Valli, Morrow, \& Yee, 2004). When people are asked to report how they feel about for example genetic modification (GM), it is possible that their response is affected due to a lack of knowledge. To avoid response biases and other problems associated with introspective verbal responses, indirect or 'implicit' measures have emerged (Fazio \& Olson; Hermans, Baeyens, \& Eelen, 2003). With the use of these indirect measures it is possible to investigate consumers' first, intuitive or even implicit evaluative impressions when they are confronted with a new food technology.

Explicit attitudes are believed to predict deliberate, well contemplated behaviour, whereas implicit attitudes are believed to predict spontaneous behaviour (Perugini, 2005). Therefore, behaviour is better predicted by both explicit and implicit attitudes than by explicit attitudes alone, since implicit measures provide information that augments that from explicit measures (Roefs et al., 2011). When correlations between explicit and implicit attitudes are high, the attitude is considered to be highly predictive of behaviour. In contrast, when correlations between explicit and implicit attitudes are low or absent, the attitude is believed to be less predictive of actual behaviour (Spence \& Townsend, 2006). Moreover, according to Hoffmann, Gawronski, Gschwendner, Le and Schmitt (2005) such a non-existing correlation between explicit and implicit attitudes is due to a lack of introspective access to implicitly assessed representations.

It can be argued that such lack of introspective access exists when people have no or little experience with a (new) object or concept. We suggest that since an attitude towards a familiar issue is generally well embedded and can be easily accessed, it will be automatically inferred from memory. Consequently the explicit and implicit evaluations of a familiar food category will be relatively more similar to each other. On the other hand, when an issue is rather unfamiliar, people have not (yet) formed a clear opinion about the 
issue. In this case, discrepancies between intuitive and explicit reactions might suggest that attitudes towards novel food technologies are not (yet) strong structures.

\section{Process-based and product-based evaluations}

Assuming that attitudes towards familiar food technologies are strong, it holds that (nonverifiable) information will be automatically derived from the superordinate level to evaluate a food product to which that technology is applied. In contrast, assuming that attitudes towards novel food technologies are in general weak, it holds that information is analytically searched for to base an evaluation (attitude) on. This latter assumption implies that the evaluation of novel foods depends on specific attributes of the product.

Several studies (Kaye-Blake, Bicknell, \& Saunders, 2005; Miles, Ueland, \& Frewer, 2005) describe two bases for consumers' evaluations about new food technologies; namely process-based and product-based. In a process-based strategy, the evaluation of a new food item is based on the general evaluation of the technological process that has been applied to create them. In contrast, when consumers' evaluation of a food product is product-based, they consider specific attributes of that product.

It can be suggested that when people have a relatively weak attitude towards a food technology, they will use a product-based evaluation strategy, whereas they will base their evaluation on their general opinion (process-based), when they have a strong attitude towards a food technology.

In the present dissertation, we aim to investigate whether food technologies differ in familiarity and in evaluation and how these constructs relate to each other. This is interesting since many studies (De Barcellos et al., 2010; Nielsen et al., 2009; Teisl, Fein, \& Levy, 2009; Rodriguez, 2007; Nayga, Aiew, \& Nichols, 2005) showed a positive relation between knowledge and attitudes towards food technologies, whereas other studies did not find any relation between these two constructs (Cox, Evans, \& Lease, 2008; Cox, Evans, \& Lease, 2007). Moreover we want to investigate whether consumers differ in attitude strength towards food technologies and whether this is related to the familiarity of the food technology. We suggest that when food technologies are novel to consumers, they have no established evaluations about these technologies and therefore no strong attitude. Furthermore there is evidence that the evaluation of food technologies is related to the provided information about these technologies. For example, Some studies (Siegrist, Stampfli, Kastenholz, \& Keller, 2008; McEachern \& Willock, 2004) showed that attitudes towards food products and food technologies become more positive when information about their merits was provided. Moreover, a study of Fischer and Frewer (2009) showed that how information is used to form perceptions about foods depends on the familiarity of those food products. This suggests that different strategies are used to process information of food technologies that differ in familiarity. We hypothesize that a product-based evaluation strategy is used to evaluate new food products in which case consumers analytically search for verifiable information. In contrast, when a food technology is familiar to consumers, we hypothesize they have established evaluations about these technologies and therefore a strong attitude (highly committed and highly central). As a result, we suggest that these consumers will evaluate the product according to their general opinion about a technology (process-based) and will therefore not involve other information in their evaluation. 


\section{Overview of the present dissertation}

The main aim of the research presented in this thesis is to understand the mechanisms underlying people's reactions towards modern food technologies. We investigated which processing and evaluation strategies are used when people are confronted with familiar and non-familiar food products.

In Chapter 2 we investigated whether specific types of food technologies differ in their perceived familiarity and in how positively they are evaluated. In a pilot study, forty-five undergraduate students were asked about their attitude, attitude strength and level of knowledge toward several food technologies (genetic modification, functional food production, organic food production, food supplements and vegetarian food production). We predicted that attitudes are more strong (highly central and highly committed) and less ambivalent when food technologies are better known to the public. In the main study of Chapter 2 we replicated the findings of the pilot study. Moreover, we used an implicit measurement (EAST) in addition to an explicit questionnaire to investigate people's attitudes and attitude strength towards a relatively novel and a relatively known food technology (respectively genetic modification (GM) and organic production (OP)). We predicted that when a food technology is well known, significant correlations between the implicit and explicit measures will be found. In contrast, we predict that when a food technology is unfamiliar, significant correlations will not be present.

In Chapter 3, we investigated in two studies whether there is a difference in the process (analytical versus automatic) by which novel and familiar food products are evaluated. In the first study seventy-four non-student consumers were asked to classify a list of food products in two groups. Several researches (Hoek, van Boekel, Voordouw, \& Luning, 2011; Bech-larsen \& Nielsen, 1999) showed that free-sorting taks are especially suitable to unravel consumers'cognitive sructures towards food products. In our first study, participants were free to divide the food products into two groups as long as they mentioned why they categorized the two groups as such. Half of the participants were told that it concerned genetically modified products. We predicted that a more analytic processing strategy is used when confronted with food products that are labelled as genetically modified because consumers are not familiar with this food technology. Moreover, we predicted that verifiable food characteristics are used to categorize GM products. Verifiable categorization criteria are empirical and observable observations of the physical characteristics of a stimulus or one's own reactions towards the stimulus (e.g. whether the product is industrially processed or not). In contrast, we predicted that a more automatic processing strategy is used when confronted with food products that are not labelled as GM. Also, we predicted that non-verifiable food characteristics are used when categorizing these products. Non-verifiable categorization criteria are beliefs that cannot be verified or tasted by the consumer (e.g. whether the product is healthy or not). The second study tested the same hypothesis, under conditions of differential cognitive load during the performance of the task. We predicted that when the use of verifiable and non-verifiable classification is associated with a distinction in information processing strategies (analytical versus automatic), inhibiting people's processing capacity would lead to relatively more use of non-verifiable classifications, because of more frequent automatic processing behaviour.

In Chapter 3 we predicted that consumers use different processing strategies (analytic versus automatic) when categorizing food products. In Chapter 4, we investigated whether different evaluation strategies (product-based versus process-based) are used when 
consumers evaluate food products that are manufactured with the use of novel and (relatively) familiar food technologies. Assuming that product-based evaluation strategies are analytical processes and process-based evaluation strategies relatively automatic processes, we suggest that product-based evaluations are more likely when food technologies are novel, while process-based evaluations are more involved when food technologies are familiar. In Chapter 4, one hundred and fourteen consumers were asked to evaluate genetically modified (GM) and organically produced (OP) food products in combination with benefits (i.e. specific advantages that are brought to a product through a technology). We predicted that the benefits were considered in consumers' evaluation when it concerned novel food products (product-based). In contrast, we predicted that benefits were not considered when they had to evaluate familiar food products (process-based). Moreover, consumers were asked about their attitude, attitude strength and level of knowledge towards the two food technologies (GM and OP). We suggest that the use of these different evaluation strategies is related to consumers' attitude strength towards a (novel or relatively familiar) food technology. Therefore we predicted that when consumers have a relatively weak attitude towards a food technology (GM), they will include the offered benefits in their evaluation of products (product-based evaluation strategy) because they analytically search for information. In contrast, we predicted that when consumers have a strong attitude towards a food technology (OP), they will not use the offered benefits for their evaluation of products (process-based evaluation strategy) because they will base their evaluation on their (automatically generated) general opinion.

In Chapter 4 we predicted that the evaluation of novel food products is product specific. Moreover, we predicted that interpersonal differences in attitude strength could explain why consumers accept novel foods to different extents. In Chapter 5, we tried to replicate the finding that the evaluation of novel food products is product specific by showing that the acceptance and evaluation of food products depends on product features such as whether the product is genetically modified or not and whether they are processed food products or not. In a pilot study, thirty-six undergraduate students were asked to evaluate three food products that have a well known non-processed form (e.g. potato) and a well known processed form (e.g. crisps). Moreover, the consumers had to evaluate these products in a GM form (e.g. GM potato and GM crisps). We predicted that whether food products are genetically modified or not and whether they are processed or not are two important features that affect the acceptance of food products and how well they are evaluated. In the main study of Chapter 5 we replicated the findings of the pilot study with one hundred and three consumers. Furthermore, we investigated whether certain nonverifiable product attributes (perceived naturalness, healthiness, necessity and tastiness) influence the effects of genetic modification and processing on acceptance.

Finally, in Chapter 6 the empirical findings from the previous chapters are summarized and critically discussed. Furthermore, limitations and strengths of this thesis will be described. We also suggest possibilities for future research and evaluate whether the presented research has provided insight into the mechanism underlying people's reactions towards new food technologies. Please note that the empirical chapters can be read independently from each other which implies that parts of the introductions of the empirical chapters have some overlap. 


\section{Chapter 2}

Intuitive and explicit reactions towards "new" food
technologies: Attitude strength and familiarity

1 This chapter is an adjusted version of the following article: Tenbült, P., de Vries, N. K., Dreezens, E., \& Martijn, C. (2008). Intuitive and explicit reactions towards "new" food technologies: Attitude strength and familiarity. British Food Journal, 110, 622-635. 
While shopping or watching commercials on television, we keep seeing advertisements for new brands of peanut butter, new kinds of candy bars or for better tasting types of soy. Many of these food innovations are distinctive because of the way they are produced (e.g., organically grown vegetables and meats, genetically modified food). One way of investigating people's attitude towards new food technologies would be to just ask people what they think about the technologies in question, i.e., measuring their attitude on a cognitive and conscious level. Another way is relying more on gut reactions: measuring people's attitudes on a more affective and unconscious level. Despite the fact that new food technologies are of increasing importance, not a lot of research into how people react implicitly to these technologies has been conducted (Spence \& Townsend, 2006).

Explicit attitudes are believed to predict deliberate, well contemplated behaviour, whereas implicit attitudes are believed to predict spontaneous behaviour (Perugini, 2005). Therefore, behaviour is better predicted by both explicit and implicit attitudes than by explicit attitudes alone. When correlations between explicit and implicit attitudes are high, they are believed to be highly predictive of behaviour. In contrast, when correlations between explicit and implicit attitudes are low or none existing, they are believed to be less predictive of actual behaviour (Spence \& Townsend, 2006).

The study of Spence and Townsend (2006) was the first ever study to examine implicit attitudes toward GM food. The study showed neutral implicit attitudes (in the context of organic food) and neutral explicit attitudes towards GM foods. The authors found no significant correlation between people's implicit and explicit attitude towards GM food. According to Hoffmann, Gawronski, Gschwendner, Le and Schmitt (2005) such a non existing correlation between explicit and implicit attitudes is due to a lack of introspective access to implicitly assessed representations.

We argue that such lack of introspective access is present when people have no experience with a new object or concept. Therefore the current study investigated whether the absence of a relation between implicit and explicit attitudes towards food technologies can be explained by the novelty of the food technology in question. This could provide further insight into whether attitudes towards food technologies are predictive of behaviour. First we will explain what attitudes are and how they can be explicitly and implicitly measured.

\section{Attitudes}

In the definition of Eagly and Chaiken an attitude is: "the psychological tendency to evaluate a particular entity with some degree of favour or disfavour" (1993: 1). Attitudes help us to make decisions and to understand and interact with our environment. The extent to which attitudes predict behaviour varies and depends among other factors on the strength of the attitude. People's attitudes become stronger when people are frequently exposed or are highly involved with an attitude-object, or when they have frequently expressed their attitude. Strong attitudes are highly embedded into people's inter- and intra-attitudinal structure. The inter-attitudinal structure encompasses a larger number of attitudes to which a certain attitude is related. For example, someone's attitude towards 'genetic engineering' can be related to someone's attitude toward 'cloning' and 'recycling'. Thus, a supporter of genetically modified foods may for example have a positive attitude towards cloning and a neutral or negative attitude towards recycling. On the other hand, attitudes are also embedded into a larger set of related concepts like for example beliefs and values. Someone's attitude toward genetic engineering can for example be influenced by beliefs 
like 'genetic engineering can help cure diseases' or by values like 'power' (Dreezens, 2006). The structure that contains these interrelated beliefs, values and attitudes is called the intra-attitudinal structure. Well embedded attitudes are strong over time and are less susceptible to context effects (and have more impact on behaviour), whereas weak attitudes are constructed on the spot and are assumed to be easily changed (Holland, Verplanken, \& Van Knippenberg, 2002). Attitude strength is conceived to consist of two important dimensions; centrality and commitment. Centrality refers to the strength of the link between an attitude and characteristics of the self ('how important is this for me'). Centrality is an aspect of the inter-attitudinal structure of an attitude because it has associations with other elements in the cognitive structure (e.g., values, personality traits, goals). Commitment refers to the accessibility of the link between an attitude object and its evaluation ('how certain am I about my opinion'). It is an aspect of the intra-attitudinal structure of an attitude because it is related to structural properties of the attitude itself (e.g., behavioural, cognitive or affective evaluations). Although centrality and commitment are moderately correlated, they are conceptually distinct. People can find for example certain issues (e.g., death penalty, nuclear power) very important, but are uncertain of whether they are in favor or against (Holland, 2003).

Holland (2003) showed that highly central attitudes are strongly embedded in the cognitive structure of the personal self. When people have highly committed attitudes, they can make decisions without much deliberation (automatically). These attitudes can easily be retrieved from memory and are held with great confidence and are therefore not easily affected by context. When commitment is low, attitudes are not strong and, due to on-line construction, are inferred from behaviour. By measuring people's attitude centrality and commitment, one can investigate whether attitudes are well embedded in their inter- and intra-attitudinal structure, or in other words how strong the attitudes are.

\section{Implicit measurement}

A problem with measuring explicit attitudes is that verbal reports depend on conscious introspection, by eliciting verbal responses to statements about feelings, beliefs and behaviour (Fazio \& Olson, 2003; Ottaway, Hayden, \& Oakes, 2001). Not all attitudes can be validly measured with explicit measurements, for example when attitudes are not readily accessible or when it concerns issues that are relatively unknown. Some food technologies, like genetic engineering, are relatively new and consumer knowledge about this technology is limited (Cuite, Aquino, \& Hallman, 2005; House, Lusk, Jaeger, Traill, Moore, Valli, Morrow, \& Yee, 2004). When people are asked to report how they feel about for example genetic modification (GM), it is possible that their response is affected due to a lack of knowledge. To avoid response biases and other problems associated with introspective verbal responses, indirect or 'implicit' measures have emerged (Fazio \& Olson; Hermans, Baeyens, \& Eelen, 2003). With the use of these indirect measures it is possible to investigate consumers' first, intuitive or even implicit evaluative impressions when they are confronted with a new food technology.

One of the most common methods to measure implicit attitudes is the Implicit Association Test (IAT), developed by Greenwald, McGhee and Schwartz (1998). The IAT is based on the assumption that task performance is better when responses are made to a pair of items that are strongly associated, than when a pair of items are weakly associated (Spence \& Townsend, 2006). The original IAT involves a relative comparison of attitudes towards two target concepts that are in some way each other's opposite (e.g., a positive or 
negative attitude towards white people compared to a positive or negative attitude towards black people) (De Houwer, 2003). Therefore, this technique is not suitable for measuring implicit reactions to concepts that are not each others opposite. After the initial IAT, many additional implicit measurement techniques have been developed (For an overview, see Fazio \& Olson, 2003). The Extrinsic Affective Simon Task (EAST) was first developed by De Houwer (2003) and is a modified version of the IAT. The EAST solves the earlier mentioned problem of the IAT: it can also be applied to single concepts. Although concepts like GM and organic production (OP) are seemingly opposite issues (e.g. in familiarity or in extent of human interference), it could be argued that the opposite of GM is in fact the absence of use of genetic engineering. OP and for example functional food production are both technologies that do not make use of genetic engineering. Because it is not clear whether GM and OP are opposite issues, we believe that the EAST is a more appropriate method to measure implicit evaluative associations towards concepts like food technologies because the EAST can be applied to both opposite and single concepts.

In the EAST, the task of the participant is to categorize words as they appear on a computer screen. Participants have to classify words on the basis of either stimulus valence when the word is printed in white (e.g., 'positive' or 'negative') or on the basis of colour when the word is printed in a colour (e.g., the colour 'purple' and the colour 'blue'), by pressing one of two response keys. This is practiced, so that each response key becomes associated with one specific valence and one specific colour, e.g., 'positive' and 'blue' on the first response key and 'negative' and 'purple' on the second response key. After practice each stimulus word (e.g., the word 'school') is presented once in purple and once in blue. When a participant has a negative association with the word 'school,' the response time for determining that the word is shown in blue (which is on the same response key as 'negative') is faster than the response time in determining that that same word is printed in purple (which is on the same response key as 'positive') (De Houwer, 2003).

\section{Current research}

As mentioned above, behaviour is better predicted by both explicit and implicit attitudes than by explicit attitudes alone. When correlations between explicit and implicit attitudes are high, they are believed to be highly predictive of behaviour (Spence \& Townsend, 2006). When correlations between explicit and implicit attitudes are low, they are believed to be less predictive of actual behaviour and are believed to be due to a lack of introspective access to implicitly assessed representations (Hofmann et al., 2005). We also mentioned that non strong attitudes are not well embedded in people's inter- and intra-attitudinal structure and are therefore not easily accessible. This might indicate that the strength of an attitude moderates the relationship between implicit and explicit attitudes. If so, it would hold that people's implicit and explicit attitudes towards an (novel) issue (e.g. GM), to which they have no strong attitude, will not correlate (or correlate modestly). In contrast, when people have a strong attitude towards an (familiar) issue, their implicit and explicit attitude towards this issue would highly correlate.

The present study aimed to investigate both explicit attitudes and implicit associations towards different food technologies. We hypothesized that food technologies differ in familiarity. We also hypothesized that attitudes towards familiar food technologies are strong (i.e. highly central and highly committed). Likewise, we hypothesized that attitudes towards novel food technologies are not strong. Besides this, we hypothesized that familiarity of a food technology moderated the relation between implicit and explicit 
attitudes. More specific, we hypothesized that implicit and explicit attitudes correlated when the attitude object was a familiar food technology. In contrast, we hypothesized that implicit and explicit attitudes did not correlate when the attitude object was a novel food technology. Additionally, this study will serve as a replication of the finding of the study of Spence and Townsend (2006), by showing that no correlation between the implicit and explicit attitude towards GM is present.

\section{Method}

In order to select two food technologies for our sample of production methods, we conducted a pilot study in which several food production technologies were compared with each other in terms of familiarity and embeddedness.

\section{Pilot Study}

In a pilot study with forty-five undergraduate students (33 females, 12 males) of Universiteit Maastricht with a mean age of 20.16 years ( $\mathrm{SD}=4.36$, ranging from 18 to 24), we investigated people's explicit attitude, attitude centrality and attitude commitment towards different processing technologies like functional food production, genetic modification (GM), organic production (OP), vegetarian production and food supplements. Two questions concerned the extent to which their first impression was positive and desirable (e.g. What is your first impression when you think of genetic modification), four questions were asked about their attitude towards the technology in question (e.g. How do you feel about genetic modification) and three questions were to rate the ambivalence of their attitude (e.g. I have doubts about my opinion towards genetic modification). Three questions assessed attitude centrality (e.g. How important is genetic modification to you?) and three questions assessed attitude commitment (e.g. How convinced are you that your opinion about genetic modification is correct?). A study of House et al. (2004) investigated the subjective and objective knowledge towards the acceptance of GM foods. The authors showed that subjective knowledge was a significant determinant of how willing consumers were to eat GM food products, whereas objective knowledge was not related to acceptance. The authors tested subjective knowledge with one single self-report item about how knowledgeable the participant believed he or she was about GM. Therefore we included one question that measured the perceived level of subjective knowledge (e.g., How knowledgeable do you believe you are about genetic modification?).

The pilot study showed that people had the most positive first impression and the most positive attitude towards OP, which was well embedded (highly central) and easy accessible (highly committed). Further, people had the most ambivalence towards GM and had the most negative attitude towards GM, which was not well embedded and not very accessible. The attitudes towards the other technologies was slightly positive, was central but was not very committed in our sample of production methods. Since GM and OP represented the two extremes in terms of embeddedness, we chose these two technologies as stimuli in our sample of production methods. The pilot study further showed that people perceived to have more subjective knowledge about OP than about GM. It can be concluded that OP is a relatively more familiar technology than GM. Besides this, it can be hypothesized that the correlation between implicit and explicit attitudes towards OP is relatively stronger than towards GM. 


\section{Sample}

Forty-seven undergraduate students (40 females, 7 males) of Universiteit Maastricht participated in the main study. The mean age of the participants was 21.72 years (SD = 4.87, ranging from 18 to 50). All participants were undergraduates of the health sciences department and all participants signed an informed consent form and received course credit for their participation.

\section{Materials}

Implicit measurement. An EAST contains white and coloured words. For the white (control) trials, in which words are categorized on the basis of valence, we used the same five positive and five negative nouns (evaluative words) as De Houwer (2003), see Table 1. For the coloured trials (where the left key has to be pressed for one colour, and the right for the other colour) we chose five nouns related to GM and five nouns related to OP (stimulus description words) (see Table 1). These nouns were selected in an unrelated pilot test among 10 employees of Universiteit Maastricht. The participants of this pilot test had to mention words that were associated to either GM or OP. We chose the 5 most frequently listed words for each category. The stimulus description words were presented in either the colour blue or purple. The colours were picked in such a way that they were quite similar in order to make sure that the participants would pay enough attention to the presented words. The EAST was presented on a 5320 Macintosh Performa computer.

Table 1.

Stimulus words used in the EAST (translated from Dutch)

\begin{tabular}{llll}
\hline $\begin{array}{l}\text { Positive attribute } \\
\text { words }\end{array}$ & $\begin{array}{l}\text { Negative attribute } \\
\text { words }\end{array}$ & $\begin{array}{l}\text { Genetic modification } \\
\text { related words }\end{array}$ & $\begin{array}{l}\text { Organic production } \\
\text { related words }\end{array}$ \\
\hline Love & Hate & Genetic modification & Organic production \\
Fortune & War & Cloning & Natural \\
Fun & Murder & Genetic manipulation & Organic food \\
Flower & Pain & Genetic technology & Organic cattle breeding \\
Peace & Death & Genetic change & Environmentally \\
& & & conscious \\
\hline
\end{tabular}

Explicit measurement. We used an electronic questionnaire that consisted of two parts. In the first part (14 questions), the participants were asked to rate on a 5-point Liker-scale the extent to which they felt positive or negative about genetically modified food products in general. Four questions were asked about their attitude towards GM (e.g., How do you feel about genetic modification) and three questions were to rate the ambivalence of their attitude (e.g., I have doubts about my opinion towards genetic modification). Three questions assessed attitude centrality (e.g., How important is genetic modification to you?) and three questions assessed attitude commitment (e.g., How convinced are you that your opinion about genetic modification is correct?). One question measured the perceived level of subjective knowledge (e.g., How knowledgeable do you believe you are about genetic modification?). 


\section{Procedure}

The participants completed the experiment on an individual basis. The experimenter welcomed the participants and told them that the experiment consisted of two separate tasks, a computer task and a questionnaire. Each would take about 10 minutes. All participants first completed the computer task, followed by the questionnaire. For technical reasons, the two tasks were done in two separate, research cubicles. The participants were seated in the first research cubicle containing only a computer on a desk and a chair.

The EAST consisted of two practice blocks and a test block. The instructions were presented on the computer screen. These instructions informed the participants that they had to classify words, depending on the valence of the word when the word was presented in white or depending on the colour of the word when the word was printed in a colour, by pressing the keys ' $a$ ' or ' 6 ' (on the numerical pad), labeled respectively as ' $L$ ' (left) and ' $R$ ' (right), of the (QWERTY) keyboard. When exposed to either a positive or blue word the participants were asked to press the ' $L$ ' key. When exposed to either a negative or purple the participants were asked to press the ' $R$ ' key. The instructions about which key to press were repeated before each practice and each test block. The words were presented in the center of the screen and appeared after a red fixation cross which was visible for $500 \mathrm{~ms}$. Participants were asked to respond as quickly and accurately as possible by classifying the target word as either positive or negative or by the colour of the word. The target word remained on the screen until the participants responded. Participants received no error message when they gave an incorrect response (e.g., classifying a positive word as negative or vice versa). In the first practice block, each of the five positive (e.g., love, fortune, flower) and five negative evaluative words (e.g., hate, war, pain) were presented twice in white letters in a random order. The second practice block consisted of 10 trials with the word 'nutrition' presented in either the colour blue or purple. The test block, containing a total of 60 trials, started with 10 warm up trials (presenting the 10 evaluative words randomly in white), followed by 50 random test trials in which the 10 evaluative words were presented twice in white, the 10 stimulus description words (target words related to GM or OP) once in each colour and the word 'nutrition' five times in each colour.

\section{Explicit attitude measurement}

After completing the computer task, the participants moved to the other research cubicle that also contained a chair and a computer on a desk. The participants were seated and were asked to answer some questions. Instructions were presented on the screen of the computer and the questions were presented in random order.

\section{Results}

\section{Method of analysis}

In this study we investigated both explicit attitudes and implicit associations towards different food technologies. We hypothesized that implicit and explicit measures correlated when people had a strong attitude towards an (familiar) issue. In contrast, we hypothesized that implicit and explicit measures would not (or less strongly) correlate when people had no strong attitude towards an (novel) issue because their attitude was not (yet) well embedded. 
First the implicit and explicit attitude of both GM and OP were measured. Paired samples tests were conducted to test whether people are more familiar (i.e. have more subjective knowledge) with OP than with GM. Correlations between subjective knowledge and attitude centrality and commitment of both GM and OP were conducted to test whether subjective knowledge increased attitude centrality and commitment. Paired samples tests were conducted to test whether attitudes towards a familiar food technology were more central, more committed and less ambivalent than towards a novel food technology. Then, correlations between the implicit measurement and explicit measurement were computed to test whether the implicit and explicit attitudes correlated when it involved a familiar food technology and to test whether the implicit and explicit attitudes did not correlate when it involved a novel food technology. To test whether significant correlations between the implicit and explicit measurements were only present when people had high attitude centrality and/or high attitude commitment, we correlated implicit and explicit attitudes towards both technologies, separately for high and low attitude centrality and for high and low attitude commitment. Likewise, we tested whether significant correlations between the implicit and explicit measurements were only present when people had high subjective knowledge about a technology, by correlating implicit and explicit attitude towards both technologies, separately for high and low subjective knowledge. EAST

Data of four participants were removed from the analysis. These participants reported to be dyslectic or their responses were too slow (more than 3 SDs from the mean response time). Only the trials in the test block in which coloured words were presented and a correct response was given were analyzed. Trials on which an incorrect response was given were discarded. Following Greenwald et al. (1998), the reaction times below $300 \mathrm{~ms}$ were recoded to $300 \mathrm{~ms}$ and reaction times above $3000 \mathrm{~ms}$ were recoded to $3000 \mathrm{~ms}$ and all latencies were log-transformed before analysis. These procedures are all standard. The means of these latencies and the percentages of errors were calculated separately for the trials that required a positive extrinsic response (i.e., printed in the colour that is associated to the key that in white trials corresponds to a positive valence) towards organic-related words, trials that acquired a positive extrinsic response towards GM-related words, trials that acquired a negative extrinsic response towards organic-related words and trials that acquired a negative extrinsic response towards GM-related words. A 2 (stimulus valence: organic versus GM) x 2 (extrinsic response valence: positive versus negative) ANOVA with repeated measures was used to analyze the mean log-transformed reaction times and the percentage of errors.

The analysis of the log-transformed reaction times showed no main effect of stimulus valence, $F<1$, and no main effect of extrinsic response valence, $F<1$. Apparently participants were not faster in giving a positive or a negative extrinsic response, and the reaction times were not influenced by whether the words were related to GM or organic. The important interaction between stimulus valence (GM versus organic) and extrinsic response valence (positive versus negative) was significant, $F(1,35)=5.67, p<0.05$. The untransformed means are displayed in Table 2; participants were faster in responding to trials in which a positive response was given to organic-related words and a negative response to GM-related words compared to trials in which a positive response was given to GM-related words and a negative response to organic-related words. We conclude that the trials in which a positive response was given to organic-related words and a negative response to GM-related words are congruent trials and the trials in which a positive 
response was given to GM-related words and a negative response to organic-related words are incongruent trials. We suggest that a positive association exists with OP and a negative association with GM.

The general EAST effect is the difference between the untransformed mean reaction times of the congruent (stimulus and response are similar) and the incongruent trials (stimulus and response differ). The EAST effect had a mean value of $59.8 \mathrm{~ms}$, a standard deviation of 155 , and an effect size of $d=0.39$. The mean untransformed reaction times and error percentages are displayed in Table 2. The analysis of the percentage of errors showed no main or interaction effects (all $F \mathrm{~s}<1$ ).

Table 2.

Mean untransformed reaction times in milliseconds (standard deviation in parentheses) and percentage of errors (standard deviation in parentheses) on target stimulus trials as a function of stimulus valence and extrinsic response valence

\begin{tabular}{|c|c|c|c|c|}
\hline & \multicolumn{2}{|c|}{ Reaction time } & \multicolumn{2}{|c|}{ Percentage of errors } \\
\hline & $\begin{array}{l}\text { Positive } \\
\text { stimulus }\end{array}$ & $\begin{array}{l}\text { Negative } \\
\text { stimulus }\end{array}$ & $\begin{array}{l}\text { Positive } \\
\text { stimulus }\end{array}$ & $\begin{array}{l}\text { Negative } \\
\text { stimulus }\end{array}$ \\
\hline $\begin{array}{l}\text { Extrinsic positive } \\
\text { response }\end{array}$ & $691(166)$ & $749(231)$ & $3.83(10.74)$ & $4.68(11.20)$ \\
\hline $\begin{array}{l}\text { Extrinsic negative } \\
\text { response }\end{array}$ & $738(215)$ & $701(163)$ & $4.26(9.27)$ & $3.40(9.63)$ \\
\hline
\end{tabular}

\section{Explicit attitude}

The 14 questions of each part of the questionnaire were divided into five categories. These categories were attitude, attitude centrality, attitude commitment, ambivalence and subjective knowledge. The four questions about attitude, the three questions about attitude centrality, the three questions about attitude commitment and the three questions about ambivalence had acceptable internal consistency (all alpha's $>.61$ ). Therefore the means of these questions can be calculated to measure attitude, attitude centrality, attitude commitment and ambivalence. The items for subjective knowledge were analyzed separately (For means see Table 3).

The means on the explicit measure for attitude and ambivalence towards GM did not significantly differ from the midpoint on the 5-point Likert-scale (Attitude; $t(46)=-.15, p=$ .88 ; Ambivalence: $t(46)=-.59, p=.56)$. This measure showed that the participants are neutral towards GM on a conscious level. On the other hand, the explicit measure for attitude and ambivalence towards OP did significantly differ from the midpoint on the 5point Likert-scale (Attitude: $t(46)=13.70, p<.01$; Ambivalence: $t(46)=-7.55, p<.01$ ). It appeared that participants have a positive explicit attitude towards OP and are not very ambivalent about their attitude (For means see Table 3). Moreover, paired samples tests showed that participants perceive OP explicitly as more positive than GM.

Paired samples tests were also conducted to test whether people are more familiar (i.e. have more subjective knowledge) with OP than with GM. Data showed that people had significantly more subjective knowledge about OP than about GM (see Table 3). This finding is in coherence with our hypothesis that food technologies differ in familiarity. 
Table 3.

Means and standard deviations of EAST effects (difference between the untransformed mean reaction times on positive and negative trials) and explicit measurements, $N=47$.

\begin{tabular}{|c|c|c|c|c|}
\hline & \multicolumn{2}{|c|}{ GM } & \multicolumn{2}{|c|}{ OP } \\
\hline & $M$ & $S D$ & $M$ & $S D$ \\
\hline EAST & $-0.06^{\mathrm{a}}$ & 0.25 & $-0.04^{b}$ & 0.19 \\
\hline Attitude $^{1}$ & $2.98^{\mathrm{a}}$ & 0.71 & $4.15^{b}$ & 0.57 \\
\hline Ambivalence $^{1}$ & $3.06^{\mathrm{a}}$ & 0.74 & $2.09^{\mathrm{b}}$ & 0.82 \\
\hline Attitude centrality ${ }^{1}$ & $1.88^{\mathrm{a}}$ & 0.51 & $2.95^{b}$ & 0.83 \\
\hline Attitude commitment ${ }^{1}$ & $2.37^{\mathrm{a}}$ & 0.53 & $2.85^{b}$ & 0.70 \\
\hline Subjective knowledge ${ }^{2}$ & $2.38^{\mathrm{a}}$ & 0.80 & $2.72^{b}$ & 0.71 \\
\hline Attitude low centrality & 1.42 & 0.26 & 2.17 & 0.24 \\
\hline Attitude high centrality & 2.22 & 0.35 & 3.44 & 0.67 \\
\hline Attitude low commitment & 1.82 & 0.28 & 2.16 & 0.27 \\
\hline Attitude high commitment & 2.68 & 0.37 & 3.30 & 0.63 \\
\hline
\end{tabular}

Note. ${ }^{1}$ Scale: 1 'very low' to 5 'very high'. ${ }^{2}$ Scale: 1 'I totally do not agree' to 5 'I totally agree'.

Means within rows with different superscripts differ, $p<.05$.

Correlations between subjective knowledge and attitude centrality and commitment of both GM and OP were conducted to test whether subjective knowledge increased attitude centrality and commitment (i.e. attitude stability). Correlations showed that subjective knowledge about GM is positively correlated with attitude centrality $(r(47)=.48, p<.001)$ and commitment $(r(47)=.37, p<.05)$ of GM. Subjective knowledge about OP is also positively correlated with attitude centrality and commitment of OP (respectively $r(47)=$ $.44, p<.05$ and $r(47)=.61, p<.001)$. This shows that when people have more subjective knowledge about GM or OP, their attitude towards these technologies became more central and more committed.

Paired samples tests were conducted to test whether attitudes towards a familiar food technology (OP) were more central, more committed and less ambivalent than towards a novel food technology (GM). Data showed that people's attitude towards OP was more positive and less ambivalent compared to GM. Besides this, participants' attitude toward OP was more central and more committed than their attitude toward GM. The attitude centrality and commitment of OP was slightly below midpoint on a 5 point Likert scale, whereas attitude centrality and commitment of GM were below midpoint on a 5 point Likert scale. This result showed that although the attitude towards OP was not highly central or highly committed, the attitude was more central and more committed than the attitude towards GM.

Note that tests for the explicit measures contain 46 degrees of freedom, for the implicit measurement only 35 degrees of freedom. The difference in number of participants is due to the removal of 11 participants that made mistakes in the implicit measurement. When the explicit measures were re-analysed with the 36 participants that remained in the analysis of implicit variables, identical results were obtained. 
Implicit measures versus explicit measures

To test whether the implicit and explicit attitudes correlated when it involved a familiar food technology and to test whether the implicit and explicit attitudes did not correlate when it involved a novel food technology, we computed the difference between the untransformed mean reaction times on positive and negative trials for both the GM related words and the OP related words. Correlations between these effects and the explicitly measured attitude, attitude centrality and attitude commitment of GM and OP related words were computed.

The data showed significant positive correlations between the EAST effect of organic related words and the explicitly measured attitude $(r(26)=-.37, p<.05)$ towards organic related words (for means see Table 3 ). No significant correlations were found between GM variables.

To test whether significant correlations between the implicit and explicit measurements were only present when people had high attitude centrality and/or high attitude commitment, we performed a median split on attitude centrality and attitude commitment for both GM and OP. Attitude centrality was divided into the subsets 'high attitude centrality' and 'low attitude centrality'. Likewise, attitude commitment was divided into the subsets 'high attitude commitment' and 'low attitude commitment'. We performed the same analysis as mentioned above, separately for high and low attitude centrality and for high and low attitude commitment (for both GM and OP). Data showed that the correlations between the EAST effect of organic related words and the explicit attitude towards OP is only present when people had high attitude centrality $(r(26)=.38, p<.05)$ or high attitude commitment, $r(26)=.39, p<.05$ towards OP. As expected, we did not find correlations between the OP variables when people had low attitude centrality or low attitude commitment towards OP and again no correlations were observed between GM variables. These results showed that attitude stability (attitude centrality and attitude commitment) appeared to moderate the correlation between the implicit and explicit measurements related to OP.

To test whether significant correlations between the implicit and explicit measurements were only present when people were familiar with a technology, we performed a median split on the reported level of subjective knowledge for both GM and OP. Subjective knowledge was divided into the subsets 'high subjective knowledge' and 'low subjective knowledge' (for both GM and OP). Paired samples tests showed that the amount of subjective knowledge about OP was indeed higher for the subset 'high subjective knowledge' than for 'low subjective knowledge' $(\underline{M}=3.21$ vs. $\underline{M}=2.00), t(47)=10.58, p$ $<0.001)$. We performed the same analysis as mentioned above, separately for high and low subjective knowledge (for both GM and OP). Data showed that the correlation between the implicit and explicit attitudes toward OP was only present when people had a high level of subjective knowledge towards OP $(r(28)=.49, p<.01)$. This result showed that the reported level of subjective knowledge appeared to be a factor that moderates the correlation between implicit and explicit measurements related to OP.

\section{Discussion}

The present research aimed to investigate both explicit attitudes and implicit evaluative associations with different food technologies. The main finding of this study is the presence of a significant correlation between the implicit and explicit attitude towards OP and the 
absence of a significant correlation between the implicit and explicit attitude towards GM. This main finding could provide insight into how attitudes towards new technologies are formed. It suggests that the attitude towards OP is highly predictive of behaviour, whereas the attitude towards GM is not predictive and open to change.

The current study showed that the participants perceive GM implicitly as more negative and OP as more positive. The explicit measure showed that the participants are neutral towards GM on a conscious level. This latter finding is in contradiction with our finding in the pilot test. The participants in the pilot test reported a slightly negative explicit attitude towards GM. On the other hand, participants appeared to have a positive explicit attitude towards OP. Moreover, the results showed that participants perceive OP explicitly as more positive than GM.; at the same time the participants are less ambivalent, have a more committed and more central attitude towards OP compared to GM. Besides this, people have more subjective knowledge about OP than about GM. These latter results replicated the findings of the pilot test.

The centrality of attitudes reflects how well attitudes are embedded, whereas commitment to attitudes reflects the accessibility of an attitude. The results of the current study suggested that people's evaluation of OP has been often accessed, maybe because people are more familiar with this technology, with the result that people's attitude towards $\mathrm{OP}$ is well embedded, easy accessible and therefore more strong. Because a significant correlation between the implicit and explicit attitude towards OP was found, we suggest that the attitude towards OP is strong. Because of this relatively strong attitude, we believe that people can infer their opinion towards OP more automatically than towards GM.

Although we found a clearly negative implicit evaluation towards GM in general, this seems, however, based on ambivalent and not on very strong convictions, probably related to the lack of subjective knowledge. People do not have an articulated opinion about GM and attitudes towards GM are therefore relatively open to change. We found no significant correlation between the implicit and explicit attitude towards GM. This latter result is in accordance with the finding of Spence and Townsend (2006) that no correlation between implicit and explicit measurements towards GM is present. We believe that this finding can be explained because people's attitude towards this relatively novel food technology is not well embedded and not easy accessible and therefore people's attitude towards GM is not (yet) strong. This result is in line with the suggestion of Hoffmann, Gawronski, Gschwendner, Le and Schmitt (2005) that such non existing correlations between explicit and implicit attitudes are due to a lack of introspective access to implicitly assessed representations.

Within OP, attitude centrality, attitude commitment and people's amount of subjective knowledge appear to moderate the correlation between the implicit and explicit measurements, which is absent within GM. It appears that this significant correlation between implicit and explicit measurement is only present in case of high attitude centrality, high attitude commitment and high amount of subjective knowledge towards OP. This latter finding suggested that the implicit and explicit attitude are similar when an attitude is well embedded and easy accessible, which is the case when the food technology is well known.

One of the criticisms of this study could be the possible influence of the fixed order of the measurements. An implicit priming effect could have impacted on responses to the explicit measurement. We judged that it was better to administer the implicit measurement 
first because carryover effects of explicit measures on implicit measures appear to be larger than vice versa (Bosson, Swann, \& Pennebaker, 2000).

Furthermore, there are some issues with our sample. It could be argued that the relatively small sample size could have biased the results. On the other hand, the study of Spence and Townsend (2006) was executed with a sample size of sixty participants and they found similar results. It could also be argued that the overrepresentation of female participants could have biased the results. A study of Cuite et al. (2005) showed that women were less likely to approve of GM foods. Thus, when the sample would be more representative for the population, a more positive explicit attitude towards GM could be expected. On the other hand, the sample used in the study of Spence and Townsend was more representative for the population ( $58 \%$ females versus $42 \%$ males) and this study also showed a neutral explicit attitude towards GM. It could also be argued that the education level and age of the participants in our sample may have biased the results. Cuite et al. showed that people who have a higher education level and people who are younger are more likely to approve of GM foods. In contrast, Noussair, Robin and Ruffieux (2004) showed that people with higher education levels are likely to be more negative towards GM. Apparently there is no consensus about the influence of gender, age and education level towards GM acceptance. Future research could focus on the effect of gender, age and education level towards explicit measurements and implicit measurements.

Another limitation of this study could be that we only studied two food technologies. Future research might focus on other food technologies and specific food products.

The current research suggests that the implicit measurement next to the explicit measurement provides insight into how well a concept is embedded in people's cognitive structure and whether the attitude is predictive for behaviour. By investigating implicit and explicit measurement one could determine the extent in which food technologies can be influenced and changed. More research is needed into how explicit and implicit attitudes relate to each other and how their combination might predict behaviour. This research validates the use of implicit measurements but at the same time it shows that there can be discrepancies between intuitive and explicit reactions that indicate that attitudes towards novel food technologies are not (yet) strong structures. 


\section{Chapter 3}

Categorizing genetically modified food products:

Effects of labelling on information processing ${ }^{2}$

\footnotetext{
${ }^{2}$ This chapter is an adjusted version of the following article: Tenbült, P., De Vries, N.K., Dreezens, E., \& Martijn, C. (2007). Categorizing genetically modified food products: Effects of labelling on information processing. British Food Journal, 109, 305-314.
} 
Since the $18^{\text {th }}$ of April 2004, food products in the European Union that contain genetically modified (GM) ingredients must be labelled as such. Advocates claim that labelling will ensure that consumers have more complete information, enabling them to make more informed choices (Conko, 2003). An important question is whether providing information about a certain product characteristic (e.g. labelling that the product is GM) affects people's perception of the food products. And if labelling does have an effect, does it lead to more reasoned choices? Our perception of the world around us depends on the interpretative concepts that we use in perceiving. Kunda (1999, p. 17) uses the terms schema, concept and mental representation interchangeably (p. 17). We will use the term 'concept'. When we encounter people, behaviours or objects, we classify them as instances of certain categories. For example, we do not see a round red object with a stalk, but we see an apple. Likewise, we do not see a man with a stethoscope, we see a doctor. Classification enables us to use our knowledge about categories and to make sense of individual members of the categories. For example, with the help of our knowledge about the concept 'doctor' we can better understand the behaviour of the man with the stethoscope (Kunda, 1999). This identification of an object belonging to a certain category leads to a process of inference; we know more about the object than we actually see.

\section{Network}

To understand how perception works, it is important to understand the way cognitive concepts are applied to stimuli and on what basis stimuli are distinguished (i.e. are categorized). Concepts are connected to each other in a network. According to modern cognitive theory (Sternberg, 1996), innumerable concepts are interconnected to each other (e.g. the concept 'fruit' is connected to 'apple'). Connections between concepts differ in strength (e.g. the concept 'fruit' has a stronger connection to 'apple' than to 'avocado'). Concepts become activated by being confronted with them or by actively thinking about them. Depending on the strength of different connections, activation of one concept will spread to other concepts. This is called the process of 'spreading activation'. A stronger connection facilitates information processing (e.g. that an apple is a kind of fruit). Because of the stronger connection between 'fruit' and 'apple' as compared to 'fruit' and 'avocado', it is more probable that 'apple' will come to mind when one has to give an example of some kind of fruit (Sternberg, 1996). The probability that a concept comes to mind depends on characteristics of the semantic network but also of temporary factors such as recency of use.

Based on the original spreading activation models, other semantic network theories and connectionist models of cognition have been developed (Niemann, Sagerer, Schroder, \& Kummert, 1990; Janiszewski \& van Osselaer, 2000).

\section{Hierarchies}

Within a network, concepts are hierarchically organized (see Figure 1). The most concrete concepts are at the bottom, and more abstract concepts are at higher levels. For example, the concept 'fruit' is at a high, superordinate level. At a lower level different categories of fruits are present, for example 'tropical fruits' and 'temperate fruits' and at the lowest, subordinate level exemplars are represented (respectively avocado and apple). (Kunda, 1999; Rosch, Mervis, Gray, Johnson, \& Boyes-Braem, 1976).

Whatever is known about items at a higher level can be inferred to all items at lower levels in the hierarchy (this is called heritance, Daelemans, Gazdar, \& De Smedt, 1992). 
Thus when you believe that fruit is healthy, an apple and a kiwi must also be healthy because they both are fruits. However, one cannot make inferences about higher order categories on the basis of characteristics of concrete lower order categories: if you believe that all apples have cores, it does not mean that all fruits have cores.

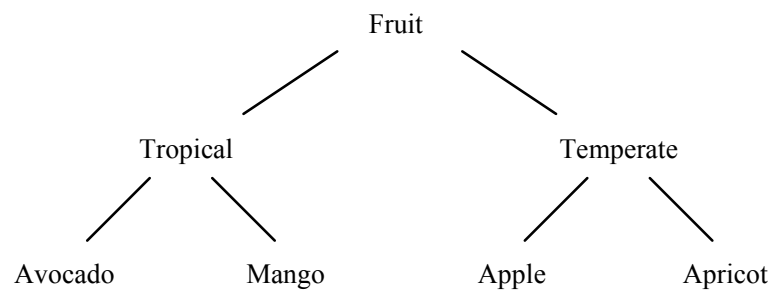

Figure 1. Hierarchy of fruit.

\section{Automatic and analytical processes}

The inference of information is an automatic process. This is a non-analytical, relatively unconscious process (Garcia-Marques \& Mackie, 2001). In automatic processing more abstract and general knowledge and evaluations can be inferred and can be used to judge objects (Grunert, Bredahl, \& Scholderer, 2003). Before information can be inferred automatically, the higher order knowledge has to be inductively constructed: information has to be generalized analytically from exemplars. When you have analyzed that an apple is healthy, that a banana is healthy and a pear is healthy, this information can be generalized into the idea that all fruits are healthy. This higher level information can then be used when you encounter other types of fruit. When an object is subsequently categorized as a fruit, it can be inferred that it is healthy. Analytic processing involves careful attention to the specifics of the situation or the object and is a relatively conscious process (Grunert et al., 2003).

\section{Labelling a new category}

People activate different aspects of their mental representation depending on which aspects are relevant (Sia, Lord, Blessum, Thomas, \& Lepper, 1999). For example, when people have to mention characteristics of an avocado, people automatically activate the concept fruit and consequently all categories of fruit (for example 'tropical fruits' and 'temperate fruits') get slightly activated too, due to spreading activation. When the avocado is classified as an exemplar of the category 'tropical fruit', this category gets activated temporarily above threshold and the needed information can be inferred (e.g. grows in warm countries). When the avocado was (falsely) classified as belonging to the category 'temperate fruit' other information would be inferred instead. Apparently, whether a concept is labelled as belonging to a certain category or another has consequences for what information gets inferred and consequently how it is perceived.

As mentioned above, higher levels in the hierarchy contain abstract concepts. We believe that these abstract general judgments are inferred to categorize non-labelled, familiar products. These abstract general judgments contain beliefs that cannot be verified or tasted by the consumer (e.g. I believe that this product is healthy, safe or natural). These abstract, non-verifiable, general judgments are called credence attributes (Steenkamp, 
1989). We assume that people initially infer a credence attribute automatically when categorizing non-labelled products and will then apply this criterion to the stimulus products in order to categorize them.

Garcia-Marques and Mackie (2001) showed that when situations are new, analytic strategies are triggered. When people have little experience with an object, they have not yet made generalizations at a higher level. So, when confronted with that new object it is hard to make inferences about the object. In this case people will have to search actively for information. GM foods are relatively new products and consumer knowledge of GM is limited (Eurobarometer, 2000).

We suggest that people in general do not know how to categorize GM products, because a category that represents these products is not readily available. Consequently, they cannot infer information automatically and have to search analytically for information in order to generalize information from the exemplars. Therefore we argue that people will use an analytic processing strategy when confronted with GM products and will search at the concrete level in the hierarchy for categorization criteria. We assume that the generalized information from the exemplars are concrete judgments. In contrast with nonverifiable categorization criteria, concrete judgments can be verified by the consumer and therefore we will refer to these criteria as verifiable criteria. Verifiable categorization criteria are empirical observable observations of the physical characteristics of a stimulus or one's own reactions towards the stimulus (e.g. 'These product are vegetable products', 'These are processed products', 'These products are products that I regularly consume', 'These products are products that I am willing to accept'). Besides this, the criteria used will give insight into which characteristics of the products are most associated (most temporary accessible) with GM labelling.

Consistent with these ideas, several investigations have shown that differences in perception account for differences in GM acceptance. Tenbült, De Vries, Van Breukelen, Dreezens and Martijn (2008) (see also Chapter 5 of this dissertation) showed that acceptance of GM products differs between processed and non-processed products. Relatedly, Frewer, Howard and Shephard (1998) showed that people accept GM more when it involved plants and less when it involved animals. We suggest that people will analytically search for these verifiable criteria when categorizing GM products.

We want to investigate whether different categorization criteria are used and, hence, different characteristics are used to judge GM-labelled products and non-labelled products. We will also examine whether different processes (analytic versus automatic) can account for these differences. We hypothesize that in general automatic processes are prevalent when categorizing conventional food products, resulting in relatively more non-verifiable categorization criteria. Besides this, we hypothesize that in general analytic processing takes place when products are labelled as GM, resulting in relatively more verifiable categorization criteria. 


\section{Study 1}

\section{Method}

\section{Sample}

Seventy-four inhabitants of Maastricht (43 women, $31 \mathrm{men}$ ) participated in this study. The mean age of participants was 40.04 years $(\mathrm{SD}=12.91$, range 18 to 69). Participants responded to an advertisement in a local newspaper, which asked for people to participate in a study about food preferences in return for a small payment.

\section{Food products}

In a pilot study, 10 participants were asked to list some products that have a non-processed and a processed form (e.g. tomato and ketchup). From the most frequently mentioned products, we chose nine products that spread over different dimensions other than on the basis of non-processed versus processed (e.g. healthy versus unhealthy products, natural versus unnatural products, vegetable versus animal products). We chose: tomato, chips, eggs, apple, steak, ketchup, potato, beef and baby food.

\section{Procedure}

The present experiment was part of a larger series of unrelated experiments. The participants had to classify the list of products into two groups. The participants were free to categorize the products as they liked as long as they described why they classified them this way. The participants received a form on which two frames were printed. The participants were asked to write the two groups of products into the two frames depending on the categorization they had made. They were asked to write beneath the two frames the criterion on which they had categorized the products. The participants were randomly assigned to one of two conditions. In the first condition, the participants were instructed to imagine that the products were genetically modified. In the second (control) condition this was not mentioned. At the end, the participants were thanked and received a payment of 10 euros (including travel compensation).

\section{Results}

The categorization criteria on the basis of which the participants classified the products into two groups were scored. Six different criteria were mentioned by the participants (whether they ate it or not, whether it was healthy or not, whether the products were vegetable or animal, whether it was natural or not, whether it was a processed product or not and whether it they accepted it or not). We regrouped the criteria in two major groups, namely the 'verifiable categorizations' (containing the criteria whether the products were 'vegetable or animal', whether the product was 'processed or not' and whether they 'accepted it or not' or 'ate it or not') and the 'non-verifiable' categorizations containing the credence criteria (whether it was 'healthy or not' and whether it was 'natural or not').

We performed a Chi-square test to compare the percentages of verifiable and nonverifiable categorization criteria on which the participants classified the non-labelled and GM-labelled products. The results showed that people tend to use more verifiable 
classification criteria when it concerned GM products and tend to use relatively more nonverifiable categorization criteria when it concerned non-labelled products $\chi^{2}(1)=4.33, p<$ 0.05 (for percentages see Table 1). This result was present for every verifiable and nonverifiable categorization criteria separately.

Table 1.

Percentages of mentioned criteria in the non-labelled and GM-labelled products, Study 1.

\begin{tabular}{lcc}
\hline & Non-labelled & GM-Labelled \\
\hline Verifiable categorizations & 44.4 & 68.4 \\
Non-verifiable categorizations & 55.6 & 31.6 \\
Total & 100 & 100 \\
\hline
\end{tabular}

\section{Discussion}

In Study 1 we investigated whether GM labelling of food products has consequences for how information is processed: people tend to use verifiable categorization criteria which we take as an indication of analytical, and when not labelled as GM they use non-verifiable distinctions due to inferential, automatic processes. Besides this we investigated whether different categorization criteria are used to judge GM-labelled food products compared to non-labelled food products. Our data showed that when people classify non-labelled products, they tend to categorize these products according to non-verifiable categorization criteria (credence attributes like healthiness and naturalness). When the products are labelled as GM, people tend to classify products according to verifiable categorization criteria (like processed or animal origin). We assume that non-labelled products are evaluated with the use of non-verifiable information that are inferred from higher order levels in the hierarchy. We therefore believe that this is an automatic process. On the other hand, we assume that in general people will use analytical processing strategies when confronted with GM-labelled products. Because people have little knowledge about GM, and therefore no inferences can be made, they will search for categorization criteria at the concrete level for, i.e. verifiable categorization criteria. Because people tend to use more verifiable classification criteria when it concerned GM products and tend to use relatively more non-verifiable categorization criteria when it concerned non-labelled products, we conclude that the type of categorization criteria that is used depends in general on whether the product is labelled or not.

The criteria used give insight into which characteristics of the products are most associated with GM labelling. Participants categorize products on the basis of whether the products were vegetable or animal, whether it was a processed product or not and whether they accepted it or not. Therefore we believe that these are the important dimensions on which people perceive GM products. 


\section{Study 2}

Study 1 showed that GM labelling leads to the use of different categorization criteria of products as compared to when foods are not labelled as such. We suggest that products become differently categorized on the basis of different processing strategies (automatic versus analytic).

Analytical processing requires attention and therefore occurs when someone is both willing and able to perform the task at hand (Kunda, 1999). Conversely, in situations where cognitive ability is inhibited, it is harder for a person to process information analytically. In this case, information has to be processed automatically. If our results are associated with a distinction in information processing strategies (analytical versus automatic), inhibiting people's processing capacity will lead to relatively more use of non-verifiable classifications, because of more frequent automatic processing behaviour.

\section{Method}

\section{Design and participants}

Our experiment used a 2 (product label: GM label versus no label) by 2 (cognitive load: load versus no load) full factorial design. A total of 166 students (140 women, 26 men) of University Maastricht were randomly assigned to one of four conditions of our experiment. The mean age of the participants was 20.77 years ( $\mathrm{SD}=4.05$, range 18 to 46 ). The participants received a payment of 3 euros in return.

\section{Materials}

Food products. We chose the same nine products as in Study 1 and we added yoghurt. We made sure that there were food products that can be classified into multiple categorizations. For example, baby food can be classified both as an animal product and as a vegetable product, beef can be seen as a non-processed product but also as a processed product. We added yoghurt because it can be classified as natural and as unnatural depending on the perceiver.

Cognitive load. In order to prevent people paying attention to the products we chose to let participants count backwards from 100 to 1 (e.g. 100, 99, 98, etcetera.). A cassette recorder recorded this in order to check that the participants performed the cognitive load task.

\section{Procedure}

Instructions stated that the participants had to divide a list of products into two groups. Again, the participants were free to divide the products as they liked as long as they described the basis for their categorization. This study consisted of four conditions. The first two conditions were the same as in Study 1. In the first condition, the participants were instructed to imagine that the products were genetically modified. In the second condition no such information was provided. The third and the fourth, cognitive load, conditions were similar to respectively the first and the second conditions, with the addition that participants were asked to count backward from 100 to 1 , while they executed the categorization task. This was audio-taped. After the participants had finished the categorization task, they were 
allowed to stop counting, irrelevant of how far they had advanced and were asked to push the stop button on the cassette recorder. As manipulation checks, participants in the third and fourth condition were also asked about whether they tried to count backwards ('I tried counting backwards as good as possible') and whether they perceived counting backwards to impede the execution of the division task ("counting backwards inhibited my performance on the task'). These two questions were rated on a Likert scale, ranging from 1 (not at all) to 5 (definitely yes). At the end, all participants were thanked and rewarded with a three-euro reward in cash.

\section{Results}

\section{Manipulation check}

The manipulation checks showed that for both the GM-labelled condition and the nonlabelled condition the cognitive load was equally perceived as highly difficult and was perceived as affecting performance to the same extent (for means see Table 2).

Table 2.

Manipulation check for cognitive load for non-labelled and GM products (5-point Likert scale).

\begin{tabular}{|c|c|c|c|c|}
\hline & \multicolumn{2}{|c|}{ Non-labelled } & \multicolumn{2}{|c|}{ GM-labelled } \\
\hline & $M$ & $S D$ & $M$ & $S D$ \\
\hline I tried to count backwards & 4.39 & 0.86 & 4.38 & 0.84 \\
\hline The counting inhibited my task performance & 4.30 & 0.55 & 4.40 & 0.55 \\
\hline
\end{tabular}

\section{Categorizations}

The categorization criteria of the four conditions were classified in the same two major groups as in Study 1, namely 'verifiable categorizations' (containing criteria whether the products were 'vegetable or animal', 'processed or not' and whether they 'accepted it or not' or 'ate it or not') and the 'non-verifiable categorizations' containing the credence criteria (whether it was 'healthy or not' and whether it was 'natural or not').

For the analysis of the data we used the hierarchical log-linear $\left(\mathrm{G}^{2}\right)$ procedure in SPSS12. To preserve statistical power, all 2-way expected frequencies were greater than 1 and not more than 20 percent were less than 5 . The hierarchical log linear analysis showed no significant 3-way interaction effect of product label, cognitive load and the tendency to use verifiable versus non-verifiable categorization categories. The analysis did show an interaction effect of product label on the tendency to use verifiable versus non-verifiable categorization categories $\left(\mathrm{G}^{2}(1)=18.38, p<0.001\right)$ and an interaction effect of cognitive load on the tendency to use verifiable versus non-verifiable categorization categories $\left(\mathrm{G}^{2}\right.$ $(1)=14.27, p<0.001)$. We did not find a significant interaction effect between label and cognitive load.

We performed Chi-square tests to compare the percentages of verifiable and nonverifiable categorizations depending on whether the products were labelled or not (for both the non-cognitive load condition and cognitive load condition) and whether cognitive load was present (for both the non-labelled and GM-labelled products). Data showed that people 
tend to use non-verifiable categorization criteria when it concerned non-labelled products and tend to use relatively more verifiable categorization criteria when it concerned GMlabelled products $\left(\chi^{2}(1)=17.98, p<0.001\right.$; for percentages see Table 3$)$. Data also showed that people tend to use verifiable categorization criteria when no cognitive load was present and tend to use non-verifiable categorization criteria when cognitive load was present $\left(\chi^{2}\right.$ $(1)=14.03, p<0.001$; see Table 3 ). This result was present for every verifiable and nonverifiable categorization criterion separately.

Table 3.

Percentages of mentioned criteria for non-labelled and GM-labelled products, with and without cognitive load, Study 2.

\begin{tabular}{|c|c|c|c|c|}
\hline & \multicolumn{2}{|c|}{ Non-labelled } & \multicolumn{2}{|c|}{ GM-labelled } \\
\hline & No load & Load & No load & Load \\
\hline Verifiable & 50 & 11.8 & 77,5 & 54.3 \\
\hline Non-verifiable & 50 & 88.2 & 22.5 & 45.7 \\
\hline Total & 100 & 100 & 100 & 100 \\
\hline
\end{tabular}

When people's processing capacity was inhibited due to cognitive load, the same pattern of more verifiable categorization criteria in the labelled condition and more nonverifiable categorization criteria in the non-labelled condition is present. However, under conditions of load the dominance of the use of non-verifiable categories was much stronger. In the GM-labelled condition, load seems to attenuate the dominance of verifiable categorization criteria (see Table 3). This result was present for every verifiable and nonverifiable categorization criteria separately.

\section{Discussion}

In Study 2 we tried to replicate the findings of Study 1 and we examined experimentally whether the results are indeed the effect of differences in processing strategies (analytic versus automatic). Study 2 showed the same pattern in relative differences as in Study 1 and showed that people tend to use non-verifiable categorization criteria when it concerned not-labelled products and tend to use verifiable categorization criteria when it concerned labelled products. Above this, Study 2 showed that people tend to use verifiable categorization criteria when no cognitive load is present and tend to use non-verifiable categorization criteria when cognitive load is present. We did not find an interaction effect between labelling and cognitive load. Inhibiting people's processing capacity leads to relatively more use of non-verifiable categorization criteria irrespective of whether the products were labelled or not. Cognitive load appears to increase more automatic processing behaviour and therefore we tentatively conclude that the results of Study 1 are due to automatic versus analytic processing. When products are not labelled as GM or when people have less processing capacity due to cognitive load, people generally apply abstract non-verifiable categorization criteria from a higher hierarchical level to subordinate 
exemplar products. Labelling a product as belonging to a relatively new and unfamiliar category of products (e.g. GM) will lead to more use of verifiable categorization criteria due to analytical processing. Additionally, the reported verifiable categorization criteria of GM-labelled products give us insight into which information is analytically searched for and are important dimensions on which people perceive GM products.

The studies reported here are subject to certain limitations. In our studies, participants were told to imagine a product was GM, and were not actually exposed to product labelling in terms of applying physical attributes (e.g. stickers). A study of Epstein and Pacini (2001) showed that visualized experience is similar to real experience. Besides this, we believe that telling people to imagine that a product is GM is labelling because it conveys information about a certain product characteristic. A further limitation of this study concerns sample characteristics. Study 1 has a wide age range; age differences could affect expertise with GM and non-GM products. However, in Study 2 we used a much smaller age range and found similar results. Besides this, Study 2 has an overrepresentation of female participants in the sample, but showed similar results as Study 1 (which has a better distribution between males and females).

Further research could focus on whether age differences and gender differences affect the usage of processing strategies and whether labelling of other types of new food production technologies (e.g. functional production) replicate our findings.

The present study provides insight into the processes that labelling as GM brings about. It can be concluded that labelling of a product as belonging to a certain category or another has consequences for what information gets inferred and consequently how it is perceived. 


\section{Chapter 4}

Evaluating food products: The relation between

evaluation strategies and attitude strength 
In literature regarding consumers' reactions towards new food technologies, two bases for evaluation are described: process-based and product-based (Kaye-Blake, Bicknell, \& Saunders, 2005; Miles, Ueland, \& Frewer, 2005). Are evaluations of new food items derived from the general evaluation of the technological process that has been applied to create them (process-based)? Or are the products evaluated on the basis of the more specific product attributes of this one exemplar within the category of the food production technology (product-based)? When consumers' evaluation of, for example, a genetically modified (GM) product is process-based, they will generalize their evaluative reaction to the process of GM in food to the specific item. Thus, for consumers who have a neutral or positive attitude towards GM it makes no difference for their evaluation whether the product is GM. Others, who might consider GM morally wrong, will not choose to consume GM foods at all. Either way, in process-based judgements the evaluation of a GM product will not vary with the specific product offered or its attributes but will be relatively dependent on general technology evaluations (Kaye-Blake et al., 2005). When consumers' evaluation of a (novel) food product is product-based, they consider the specific attributes of the food item. For example, some consumers find GM more acceptable when it involves plants, compared to when it involves animals (Frewer, Howard, \& Shepherd, 1996). Others find genetic modification more acceptable when it is applied to reduce the use of pesticides than when it is used to reduce production prices (Pew Initiative, 2003). For these people, a specific benefit from GM affects the evaluation of food items.

Kaye-Blake et al. (2005) studied these process-based versus product-based evaluations. The authors showed that for some consumers the decisive factor in evaluating genetically modified foods is the process of gene technology, while for others the products are differently evaluated according to their enhanced attributes, like benefits. Unfortunately, Kaye-Blake et al. do not explain why some consumers use process-based evaluations and why some other consumers base their reaction on product characteristics.

It can be assumed that process-based evaluation strategies are heuristic or relatively automatic processes; whereas product-based evaluation strategies are relatively analytical processes. In automatic processing, judgements rely on general and abstract evaluations and knowledge (Grunert, Bredahl, \& Scholderer, 2003). Likewise, process-based evaluations of new food items are based on the general evaluation of the technological process to create them. In contrast, analytic processing involves careful attention to the specifics of an object and is a relatively conscious process (Grunert et al., 2003). In product-based evaluation then, products are evaluated on the basis of more specific attributes of this one exemplar within a category of food production technology.

Research of Tenbült, De Vries, Dreezens and Martijn (2007) (see also Chapter 3 of this dissertation) showed that the use of automatic versus analytical information search strategies is related to the novelty of a food technology. The authors showed that when people are confronted with a food technology they are relatively unfamiliar with (e.g. genetic modification), they will actively search for information to base their evaluation on (an analytical strategy). In contrast, when people are confronted with a relatively familiar technology (e.g. traditional production), their evaluation will be based on general judgments (a relatively automatic strategy). Assuming that product-based evaluation strategies are relatively analytical processes and process-based evaluation strategies relatively automatic processes, this would imply that product-based evaluations are more likely when food technologies are novel, while process-based evaluations prevail when food technologies are familiar. 
In addition, Tenbült, De Vries, Dreezens and Martijn (2008) (see also Chapter 2 of this dissertation) showed that people have fairly weak attitudes towards technologies that are novel to them (e.g. GM) and fairly strong attitudes towards technologies that are relatively familiar to them (e.g. organic production, OP). Therefore it can be hypothesized that product-based evaluations are more likely when consumers have a weak attitude towards a (novel) technology, while process-based evaluations are more involved when consumers have a strong attitude towards a (familiar) technology.

\section{Attitude strength}

An attitude in the definition of Eagly and Chaiken is: "the psychological tendency to evaluate a particular entity with some degree of favour or disfavour" (1993: 1). Attitude strength has been conceptualized in terms of two dimensions; centrality and commitment. Centrality refers to the strength of the link between an attitude and characteristics of the self ('how important is this for me'). Centrality is an aspect of the inter-attitudinal structure of an attitude because it has associations with other elements in the cognitive structure (e.g., values, personality traits, goals). Commitment refers to the accessibility of the link between an attitude object and its evaluation ('how certain am I about my opinion'). It is an aspect of the intra-attitudinal structure of an attitude because it is related to structural properties of the attitude itself (e.g., behavioral, cognitive or affective evaluations). Holland (2003) showed that highly central attitudes are more strongly embedded in the cognitive structure of the personal self. On the other hand, when people have highly committed attitudes, they can make decisions without much deliberation (automatically). Another important aspect that is related to attitude strength is ambivalence. According to Armitage and Connor (2000) ambivalence occurs when a person has both strong negative and strong positive evaluations toward an attitude-object. In the present study we therefore operationalize attitude strength in terms of centrality, commitment and ambivalence.

\section{The present study}

As mentioned above, Kaye-Blake et al. (2005) showed that for some consumers the decisive factor in evaluating genetically modified foods is the process of gene technology, while for others it is the enhanced attributes of GM foods, like benefits. Recent literature (Tenbült et al., 2007; Tenbült et al., 2008) suggests that it is plausible that the use of these different evaluation strategies is related to consumers' attitude strength towards a (novel or relatively familiar) food technology. The main research question is therefore whether attitude strength is associated with the use of different evaluation strategies. We hypothesize that evaluations of food products are generally more process-based when consumers have a strong attitude towards a food technology, and more product-based evaluated when consumers have a weak attitude towards the production technology. More specifically, we hypothesize that consumers will consider offered benefits in their evaluation (product-based) when they have a weak attitude towards a technology. In contrast, we hypothesize that when consumers have a strong attitude towards a technology, they will evaluate the product according to their general opinion about the technology (process-based) and will not consider the provided benefits in their evaluation.

In addition, because food technologies differ in perceived familiarity (e.g. organic production (OP) is a more familiar food technology than GM) and because consumers can differ in attitude strength towards one food technology (Tenbült et al., 2008), we hypothesize that the effect of attitude strength on the use of different evaluation strategies 
will be present not only between food technologies, but also between persons with weak and strong attitudes.

\section{Method}

\section{Pilot Study}

In order to find the most prominent benefits offered by a relatively novel and a relatively familiar food technology, we asked 19 consumers (12 women, 7 men) with a mean age of 27.33 years ( $\mathrm{SD}=2.12$, range 24 to 32 ) to list possible benefits of genetic modification (GM) and organic production (OP). The most frequently mentioned benefits for GM were to promote health, to make products taste better and to increase the world's food production. The most frequently mentioned benefits for OP were to promote people's health and to make products taste better.

\section{Sample}

One hundred and fourteen consumers (63 women, 51 men) participated in this study. Mean age of the participants was 47.1 years $(S D=16.93$, range 18 to 82 ). Participants were randomly selected from a Dutch Internet research panel and were asked to complete an electronic questionnaire.

\section{Procedure}

The present experiment was part of a larger series of unrelated experiments. The experiment consisted of two tasks. First, participants were asked to fill out a computerized questionnaire that consisted of fifteen questions about each of two food technologies (GM and OP). Four questions measured the attitude (e.g., How do you feel about GM?). Seven questions were used to assess attitude strength: three questions assessed attitude centrality (e.g., How representative of your values is your attitude toward GM?), and four questions assessed attitude commitment (e.g., How certain are you that your opinion about GM is correct?). Besides this, three questions measured ambivalence (e.g., I have doubts about my opinion towards GM). The questions for centrality, commitment and ambivalence were derived from a study of Dreezens, Martijn, Tenbült, Kok and De Vries (2005). Finally, one question measured perceived familiarity in terms of the amount of knowledge towards a technology. A study of House, et al. (2004) investigated the subjective and objective knowledge towards the acceptance of GM foods. The authors showed that subjective knowledge was a significant determinant, whereas objective knowledge was not related to acceptance. The authors tested subjective knowledge with one single self-report item about how knowledgeable the participant believed he or she was about GM. Therefore we included this question that measured the perceived level of subjective knowledge (e.g., How knowledgeable do you believe you are about GM/OP?). The fifteen questions were asked on a 5-point Likert scale ranging from 1 ('very little') to 5 ('very much').

In the second task, participants were randomly assigned to one of two conditions (GM and OP). In the first condition participants were asked to answer questions about a GM food product. We used three questions to measure to what extent it would be accepted ('I will eat this product'; 'I will buy this product' and 'I will accept this product'). The participants were asked to imagine a GM product and these three questions were asked in combination with each of the benefits (health, taste, productivity) towards GM (e.g. 
'Imagine a genetically modified food product with the benefit to increase your health; I will buy this product'). Furthermore, the three questions were also asked without mentioning a benefit (e.g. 'Imagine a genetically modified food product; I will buy this product'). In the second condition the same questions were asked but then related to OP (with the benefits: health, taste, no benefit). All questions were asked on a 5-point Likert scale ranging from 1 ('I totally do not agree') to 5 ('I totally agree'). A sixth answering category was added labelled as 'I do not know'. At the end, the participants were thanked.

\section{Results}

We hypothesized that the evaluation of food technologies depends on offered benefits (product-based) when consumers have a weak attitude towards a technology, whereas the evaluations will not depend on benefits when consumers have a strong attitude towards a technology (process-based).

The four questions about attitude and the three questions about ambivalence had acceptable internal consistency (all alpha's $>.68$ ). Therefore the means were separately calculated to measure attitude and ambivalence. Paired samples T-tests showed that the participants have a more positive attitude and are less ambivalent towards OP than towards GM. Also, they feel they are more knowledgeable about OP than about GM (for means see Table 1).

Table 1.

Means, standard deviations and number of participants for the attitude, attitude strength, ambivalence and amount of knowledge of GM and OP.

\begin{tabular}{lcccccccc}
\hline & \multicolumn{3}{c}{ GM } & & \multicolumn{3}{c}{ OP } \\
\cline { 2 - 4 } \cline { 5 - 7 } & $M$ & $S D$ & $N$ & & $M$ & $S D$ & $N$ & $t$ (paired) \\
\hline Attitude & 2.44 & 1.01 & 57 & & 3.87 & 1.00 & 57 & $-7.21^{* *}$ \\
Attitude strength & 2.74 & 0.68 & 57 & & 3.27 & 0.85 & 57 & $-3.52^{*}$ \\
Ambivalence & 2.91 & 0.90 & 56 & & 2.45 & 0.72 & 57 & $2.86^{*}$ \\
Knowledge & 2.11 & 0.96 & 57 & & 3.02 & 1.13 & 57 & $-4.57^{* *}$ \\
\hline
\end{tabular}

Note. $* \mathrm{p}<0.01, * * \mathrm{p}<0.001$

The seven questions that were used to assess attitude strength towards GM and OP had acceptable internal consistency (alpha GM: 0.60; alpha OP: 0.75). Means were calculated and for both technologies, attitude strength was divided into 'weak' and 'strong' with the use of a median split. A t-test showed that the attitude of consumers towards OP is significantly stronger than towards GM (see Table 1). T-tests also showed that within one technology (either GM or OP) the weak and the strong attitudes differed significantly from each other (both $p$ 's $<0.001$ ).

To test whether the evaluation of benefits towards GM and OP differed between participants with weak and strong attitudes towards this technology, we used a mixed ANOVA with benefits as within variable (healthiness, tastiness and no benefit), technology as a between variable (GM versus $\mathrm{OP}$ ) and attitude strength as a covariate (weak versus strong). The analysis showed no main effect for benefits, $F(2,206)=1.34, p=0.26$. Unfortunately the interaction effect between benefits and technology was also not 
significant, $F(2,206)=1.04, p=0.35$. Likewise, no significant interaction effect was found between benefits and attitude strength, $F(2,206)=1.03, p=0.36$. These results showed that the evaluation of benefits does not differ between the two technologies and moreover that attitude strength is not of influence.

It could be argued that we did not find significant interaction effects because of the limited number of benefits. In the pilot study only two matching benefits (healthiness and tastiness) were mentioned for both GM and OP, next to the control condition (no benefit). This could have influenced the results of the analysis in such a way that no significant results were found. To see whether benefits are differently evaluated by the participants depending on the technology and differences in attitude strength, we chose to test the hypotheses separately for GM and OP.

To test whether the evaluation of benefits towards GM differed between participants with weak and strong attitudes towards this technology, we used a mixed ANOVA with benefits as within variable (healthiness, productivity, tastiness and no benefit) and attitude strength as between variable (weak versus strong). The analysis showed a main effect for benefits, indicating that participants are least negative when GM is applied to increase people's health and are the most negative when GM is applied to increase the world's food production, $F(3,156)=10.27, p<0.001$. The evaluation of GM when it is applied to improve the taste of a product is in between these values and did not differ from when no benefit was mentioned (for means see Table 2). All means are below the midpoint of the scale (3). The interaction effect between benefits and attitude strength was not significant, $F(3,156)=1.89, p=0.13$. Also, we did not find significant correlations between the evaluations of the benefits and attitude strength as a continuous variable. Thus it remains indecisive whether participants with a weak attitude towards GM evaluate the benefits differently than participants with a strong attitude towards GM.

Table 2.

Means and standard deviations of acceptance of the benefits 'health, productivity, tastiness and no benefit' for genetic modification (GM) and organic production (OP).

\begin{tabular}{lccccc}
\hline & \multicolumn{2}{c}{ GM } & & \multicolumn{2}{c}{ OP } \\
\cline { 2 - 5 } \cline { 5 - 6 } & $M$ & $S D$ & & $S$ & $S D$ \\
\hline No benefit & $2.64^{\mathrm{a}}$ & 1.18 & & $3.50^{\mathrm{a}}$ & 0.93 \\
Health & $2.93^{\mathrm{b}}$ & 1.15 & $3.62^{\mathrm{a}}$ & 1.06 \\
Productivity & $2.41^{\mathrm{c}}$ & 1.17 & & \\
Tasty & $2.65^{\mathrm{a}}$ & 1.17 & & $3.48^{\mathrm{a}}$ & 1.07 \\
\hline
\end{tabular}

Note. Means within columns with different superscripts differ, $p<0.05$

To test whether the evaluation of benefits towards OP differed between participants with weak and strong attitudes towards this technology, we used a mixed ANOVA with benefits as within variable (healthiness, tastiness and no benefit) and attitude strength as between variable (weak versus strong). The analysis showed no main effect for benefits, $F(2,88)=1.45, p=0.24$. This indicates that the evaluation of OP did not differ significantly between offered benefits (for means see Table 2); all means were around the neutral point on the scale. Besides this, we also did not find an interaction effect between benefits and attitude strength, suggesting that consumers with a weak attitude towards OP 
did not evaluate the benefits significantly differently than consumers with a strong attitude towards OP, $F(2,88)=1.01, p=0.37$. Furthermore, we did not find significant correlations between the evaluations of the benefits and attitude strength as a continuous variable. It appears that within one food technology (either GM or OP), there is no preferential use of evaluation strategies as a function of attitude strength. Moreover, we found similar results for differences within participants regarding centrality, commitment, ambivalence and knowledge.

It could be argued that although the participants differed in attitude strength within one technology, they did not differ in their perceived familiarity of the technology in question. This might suggest that within one technology, the use of different evaluation strategies is not associated with attitude strength, but with the familiarity of food technologies. Consequently we tested whether the evaluation of benefits toward GM and OP differed between persons with low and high levels of knowledge towards these technologies. Knowledge about a food technology was divided into 'low' and 'high' knowledge with the use of a median split. T-tests showed that the low and high amounts of knowledge towards either GM and OP differed significantly (both $p$ 's $<.001$ ). Data showed a main effect for benefits towards GM, $F(3,156)=8.62, p<0.001)$. Moreover we found no interaction effect between the benefits towards GM and amount of knowledge, $F(3,156)=0.38, p=$ 0.77. Also, we found no main effect for benefits towards OP, $F(3,102)=0.50, p=0.61$. Furthermore, we found no interaction effect between the benefits towards OP and amount of knowledge, $F(3,102)=0.34, p=0.85$. Not surprisingly the amount of knowledge about a food technology correlated positively with attitude strength as a continuous variable (GM: $r(57)=.54, p<.001$; OP: $r(52)=.66, p<.001)$.

To summarize, attitudes towards GM are less strong and more ambivalent than towards OP. Besides this, it can be tentatively concluded that for the evaluation of GM benefits matter, whereas for OP they do not. Furthermore, we have no evidence to assume that within a technology there is a preferential use of evaluation strategies as a function of attitude strength or as a function of perceived familiarity.

\section{Discussion}

In the present study we tried to explore factors associated with different evaluation strategies. We hypothesized that consumers with a weak attitude towards a food technology use a (analytical) product-based information search strategy, whereas consumers with a strong attitude towards a food technology use a (automatic) process-based information search strategy. More specifically, we hypothesized that the evaluation of food technologies depends on offered benefits (product-based) when consumers have a weak attitude towards a technology, whereas the evaluations will not depend on benefits when consumers have a strong attitude towards a technology (process-based).

In line with the study of Tenbült, et al. (2008), this study showed that consumers have a relatively weak attitude towards GM and a relatively strong attitude towards OP. Furthermore, we found some evidence that benefits are only differently evaluated in case of GM. No such effect was present regarding OP. As mentioned in the introduction, Tenbült et al. (2007) showed that when people are confronted with a relatively new food technology, like GM, they will actively search for information to base their evaluation on. This analytical information strategy could explain why the benefits are only considered in the evaluation when it concerned GM. We therefore assume that the evaluation of GM is 
product-based. In contrast, Tenbült, et al. argued that people use an automatic evaluation strategy when they are confronted with a relatively familiar technology and will therefore evaluate the technology on general judgments. It could be questioned whether OP is a familiar food technology. In line with the study of Tenbült et al. (2008), we found that subjective knowledge about OP is around the midpoint of the scale (3). Because people are more knowledgeable about OP than about GM, we consider OP to be a relatively familiar technology. We therefore suggest that the absence of differences in evaluation between the benefits towards OP can be explained by a process-based evaluation strategy. It can be suggested that people evaluate organic food products according to the general evaluation of the technological process that has been applied to create them. On the other hand, we suggest that GM food products are evaluated on the basis of more specific attributes (like benefits) of this one exemplar within the category of the food production technology (product-based).

Unfortunately this study is inconclusive about whether the use of different evaluation strategies can be explained by differences in consumers' attitude strength. Although we did find evidence that different evaluation strategies are used when consumers differ in attitude strength towards food technologies (product-based when attitudes towards a technology are in general weak (GM) and processed based when attitudes towards a technology are in general strong (OP)), our results did not show that different evaluation strategies are used when consumers differ in attitude strength within one technology (either GM or OP). It must be noted that this could be the result of a type two error due to the relatively small sample size. Although the (median split) division of attitude strength into weak and strong led to a significant difference in strength, further research with a larger sample size should investigate the preferential use of evaluation strategies as a function of attitude strength towards one technology (either GM or OP).

We also tested the alternative, that not attitude strength but the familiarity of food technologies is associated with the use of different evaluation strategies. However, results were similar. Although it can be debated whether measuring subjective knowledge is an appropriate way to measure familiarity, we tentatively conclude that the level of knowledge that consumers have about a food technology is not associated with the use of different evaluation strategies.

Another limitation could be that consumers were asked to imagine a GM or OP product. It could be the case that the evaluations of the consumers were affected by the kind of product they imagined. Future research could control for this possible bias by asking consumers to imagine a specific food product. Also, we did not confront consumers with actual products. Moreover, we investigated a limited number of benefits. Further research could investigate whether similar results are found with other benefits. Another limitation is that benefits are always positive. It would be interesting to investigate negative characteristics of food products. It could be argued that the selected benefits for OP all relate to the single construct 'OP is good'. Although this is in line with a process-based evaluation strategy, it is interesting to investigate whether people also use a process-based evaluation strategy when a product characteristic is offered that is not in line with this single construct, like higher pricing. Furthermore, a limitation of this study could be that we used an internet panel and that we only asked the questions about attitude, attitude strength and ambivalence towards the food technologies and not towards the benefits of these technologies. But despite these limitations we randomized the order of the benefits within food technologies and the questions about the benefits and we used non-student consumers. 
We conclude that it is indecisive whether attitude strength is a factor related to consumer evaluation of new food products that can either be based on the technology that has been used to produce them (process-based) or on a product characteristic (productbased). Although we did find evidence for the predicted (between groups) effect of attitude strength on evaluation strategies, there was no evidence for (within groups) preferential use of evaluation strategies as a function of attitude strength towards one technology (either GM or OP). Likewise it remains indecisive whether the familiarity of a food technology is a factor associated with the use of different evaluation strategies. Although we found similar results, it must be noted that familiarity and attitude strength are highly correlated. Future research could focus on whether similar results are found with other benefits and with more specific products. Moreover, future research could focus on other factors that are associated with the use of different evaluation strategies and hopefully more insight can be provided about why people use different evaluation strategies. 


\section{Chapter 5}

Acceptance of genetically modified foods: The relation between technology and evaluation ${ }^{3}$

${ }^{3}$ This chapter is an adjusted version of the following article: Tenbült, P., De Vries, N.K., Van Breukelen, G., Dreezens, E. \& Martijn, C. (2008). Acceptance of genetically modified foods: The relation between technology and evaluation. Appetite, 51, 129-136. 
Acceptance of new food technologies, especially of genetically modified (GM) foods, has recently attracted much attention in research. It has been related to trust and confidence in science, government and biotechnology companies and to socio-demographic factors (Hossain, Onyango, Adelaja, Schilling, \& Hallman, 2002; Onyango \& Nayga, 2004), to information provided about GM (Grunert, Bredahl, \& Scholderer, 2003) and to the nature of the GM technology that has been used (Burton \& Pearse, 2003; Frewer, Howard \& Shepherd, 1998). These studies provide insight into personal differences between consumers related to the acceptance of GM and whether information about the applied technology influences this acceptance. But these investigations do not show whether and how acceptance of GM foods relates to specific features of products. Does the nature of a genetically modified product influence its evaluation? And if so, why are some GM products less or more likely to be accepted?

People's acceptance of GM foods has been shown to depend on their general attitudes towards genetic engineering (Frewer et al., 1998). Many studies (Bredahl, 2001; Gamble, Muggleston, Hedderley, Parminter, \& Vaughan, 2000; Grunert et al., 2003; Saba \& Vassallo, 2002; Tenbült, De Vries, Dreezens, \& Martijn, 2008) showed that the general attitude towards the application of GM in food production is negative. Therefore, GM products are in general less well accepted than their conventional counterparts.

But general attitudes are not the sole predictors of people's attitude towards GM. Some studies (Frewer, Howard, \& Shepherd, 1996; Tenbült, De Vries, Dreezens, \& Martijn, 2005) provide evidence that although people have a general negative attitude towards GM, evaluations are product specific and not unconditionally associated with the technology overall. For example, some consumers find GM more acceptable when it involves plants, compared to when it involves animals (Frewer et al., 1996). Others find genetic modification more acceptable when it is used to reduce the use of pesticides than when it is used to reduce prices (Pew Initiative, 2003).

Gamble et al. (2000) suggest that the effect of genetic modification differs between product categories because genetic modification is a feature that affects the evaluation of products. The authors showed that the production technology (GM) is more important for consumers' evaluation of products when it concerns apples than when it concerns chocolate biscuits. The authors suggested that because chocolate biscuits are already seen as unhealthy, consumers are indifferent to whether the production technology adds to this unhealthiness.

A study of Tenbült, De Vries, Dreezens and Martijn (2007) (see also Chapter 3 of this dissertation) showed that whether food products are processed or appear in their natural form is an important factor in determining the acceptance of GM products. This may suggest that processing of products, in addition to genetic modification, are two important features that affect consumers' evaluation of products and consequently their acceptance. To illustrate this with an example from Gamble et al. (2000), apples are nonprocessed products (have their natural form) and chocolate biscuits are manufactured and therefore processed products. The evaluation of chocolate biscuits is (already) negatively affected by processing. Therefore the production technology (GM) affects the evaluation of a processed product (chocolate biscuits) less than when the product was not previously processed (apples).

The aim of the present study is to examine how genetic modification affects the evaluation and acceptance of processed and nonprocessed food products. We hypothesize that GM and processing are both features that affect the acceptance of products. We also 
hypothesize that the extent to which the acceptance of a product is affected by GM or processing depends on whether it is already negatively affected by the other feature: the acceptance of GM foods will be less sensitive to processing effects than the acceptance of non-GM food and the acceptance of processed food products will be less affected by GM than the acceptance of nonprocessed food.

In the study of Gamble et al. (2000) perceived healthiness is measured as a decisive factor in product evaluation. In other studies evaluations of other product attributes like perceived naturalness (Frewer et al., 1996; Tenbült et al., 2005; Rozin, Spranca, Krieger, Neuhaus, Sunllo, Swerdlin, \& Wood, 2004), perceived tastiness (MAPP annual report, 2000) and perceived necessity (Tenbült et al., 2005) were used to explain why GM products are less well accepted than their conventional counterparts. We hypothesize that the extent to which these evaluations of product attributes (perceived naturalness, healthiness, necessity and tastiness) are affected by GM or processing depends on whether the product is negatively affected by an other feature. Hence, the evaluation of product attributes of GM food will be relatively insensitive to processing effects and the evaluation of product attributes of processed food products are relatively unaffected by GM. Moreover, we will investigate to what extent these product attribute evaluations mediate the effects of GM and processing on product acceptance, under the assumption that these attributes affect product acceptance rather than just being correlated with acceptance.

\section{Method}

\section{Pilot Study}

In a pilot-study with thirty-six undergraduate students (21 women, 15 men) of Universiteit Maastricht with a mean age of 20.23 years $(\mathrm{SD}=2.04$, range 18 to 30 ) we investigated the extent to which genetic modification and processing affect acceptance. We used three food products that have well known processed forms and nonprocessed forms. The selected products were potato (with crisps as processed form), tomato (with ketchup as processed form) and chicken meat (with chicken fingers as processed form). In total, participants had to respond towards twelve products, three conventional nonprocessed products (e.g. tomato, potato and chicken), three conventional processed products (ketchup, crisps and chicken fingers), three GM nonprocessed products (e.g. GM tomato, GM potato and GM chicken) and three GM processed products (e.g. GM ketchup, GM crisps and GM chicken fingers). Seven questions were asked for each of the twelve products. Four of them measured the extent to which the products were seen as "natural", "necessary", "healthy" and "tasteful". Three questions were used to measure to what extent the genetically modified variant of that certain product would be accepted (e.g. 'I will eat this (product)'. These three questions were averaged into one acceptance score per person per condition, which had a satisfactory internal consistency (alpha $>0.76$ in each condition).

Because all five dependent variables (attributes and acceptance) were measured on the same five-point scale and thereby commensurate, a 2 (technology: GM versus non-GM) x 2 (processing: processed versus nonprocessed products) x 5 (outcome: acceptance, naturalness, healthiness, necessity, tastiness) within-subject ANOVA was run. Highly significant $(\mathrm{p}<0.001)$ interactions were found of technology, processing and technology $\mathrm{x}$ processing with outcome, implying that experimental effects varied between dependent variables. Therefore, a 2 (technology) x 2 (processing) within-subject ANOVA was run per dependent variable. These five two-way within-subject ANOVAs showed main effects for 
technology (all p's $<0.001$ ), main effects for processing (all p's $<0.001$, except for tastiness) and significant interaction effects (all $p$ 's $<0.001$, except for tastiness). The results showed that GM products are less well accepted and are perceived as less natural, healthy, necessary and tasty than conventional products. Likewise, processed products are less well accepted and are perceived as less natural, healthy and necessary than nonprocessed products. Besides this, the interaction effects showed that the effect of GM on a products' acceptance, perceived naturalness, healthiness or necessity is smaller for processed food than for nonprocessed food. Likewise, the effect of processing on a products' acceptance, perceived naturalness, healthiness or necessity is smaller for GM than for non-GM food. Although the pilot study showed that GM and processing both affect the evaluation and the acceptance of foods, the interaction effect might perhaps be the result of a floor effect: the processed non-GM products in this study were perceived as not natural, not healthy and not necessary for people's diet (all means below the midpoint of the 5-point Likert scale). This might have reduced the maximum attainable GM effect for processed products. Based on these results and to exclude the possibility of a floor effect we decided to use food products in our main study that have a perceived natural and perceived healthy processed form in addition to their nonprocessed form.

\section{Sample}

One hundred and three consumers (63 women, 31 men and nine who did not report their gender) participated in this study. The mean age of the participants was 39.75 years (SD = 13.52, range 18 to 69). Participants responded to an advertisement in a local newspaper, which asked for people to participate in a study about food preferences in return for a small payment. The participants completed the experiment on an individual basis.

\section{Design}

We used a two by two within-subjects design, with GM yes/no and processing yes/no as within-subject factors, acceptance as outcome and perceived naturalness, healthiness, necessity and tastiness as possible moderators and mediators.

\section{Materials}

Food products. We selected two food products that have a natural, well known processed form in addition to their nonprocessed form. The selected products were an apple (with apple juice as processed form) and an orange (with orange juice as processed form). We suggest that apple juice and orange juice are both perceived in general as natural, healthy products although they are processed. These four products were presented in a nonGM and a genetically modified form. In total, participants had to respond towards eight products, two conventional nonprocessed products (e.g. apple and orange), two conventional processed products (apple juice and orange juice), two GM nonprocessed products (e.g. GM apple and GM orange) and two GM processed products (e.g. GM apple juice and GM orange juice). First seven questions were asked about each of the four nongm products, with the products presented in a random order; subsequently, the four GM products were presented in random order and rated on each of the seven scales.

Questionnaire. Seven questions were asked for each of the eight products. Four of them measured the extent to which the products were seen as "natural", "necessary", "healthy" and "tasteful" ('I believe this (product) is natural', 'I believe this product is healthy', 'I believe this (product) is healthy', 'I believe this (product) is tasteful'). We will 
refer to these four questions as evaluation attributes. The remaining three questions were used to measure to what extent the genetically modified variant of that certain product would be accepted ('I will eat this (product)', 'I accept this (product)', 'I trust this (product)'). To make a clear distinction, the non-GM products will be referred to as conventional products. The genetically modified variants of the conventional products will be referred to as GM products.

The three questions about acceptance ('I will eat this (product)', 'I accept this (product)', 'I trust this (product)') had satisfactory internal consistency (alpha $>0.71$ in each condition ). Therefore these three questions were reduced to one acceptance measure by calculating the mean of these three questions for each of the eight products. Subsequently, the means of the two conventional nonprocessed products (i.e. apple and orange) were calculated per outcome (perceived naturalness, healthiness, necessity, tastiness and acceptance), and likewise for the two GM nonprocessed products, the two GM nonprocessed products, and the two GM processed products, giving one measure per person per condition per dependent variable. Factor and reliability analysis of these five dependent variables were conducted for each experimental condition separately and showed these variables to be highly correlated, suggesting reduction of variables into one overall acceptance or attitude outcome variable. On the other hand, ANOVA showed experimental effects to vary between the five dependent variables, justifying an ANOVA per dependent variable (for details see the Results section).

\section{Procedure}

The experimenter welcomed the participants and they were told that the experiment consisted of the completion of one $10 \mathrm{~min}$ questionnaire. The participants signed an informed consent form and were seated in a research cubicle containing only a computer on a desk and a chair. The instructions were presented on the computer screen. The instructions informed the participants that the questionnaire consisted of two parts and that they had to answer 7 questions about four conventional food products by pressing a 1 (I totally do not agree), 2 (I do not really agree), 3(I do not know), 4 (I agree a bit) or a 5 (I totally agree). Then, the participants were asked to imagine one of the four products (the order was determined at random for each participant) for a moment after which the 7 questions (in random order) had to be answered. The questions were presented in the centre of the screen and appeared after a red fixation cross which was visible for $1000 \mathrm{~ms}$. Answering alternatives were shown on the screen. The question remained on the screen until the participants responded. When the first part of the questionnaire was completed, another instruction on the screen informed the participants that in the second part they would have to do the same as in the first part, but with the difference that they now had to imagine the same products in a genetically modified form. At the end of the questionnaire, the participants were thanked.

\section{Results}

We are interested in the relation between acceptance of food products and the extent to which genetic modification and processing affect acceptance. We hypothesize that GM and processing both affect the acceptance and the evaluation (perceived healthiness, naturalness, necessity and tastiness) of products. We also hypothesize that the extent to 
which GM or processing affects the acceptance and evaluation of a product depends on whether it is already negatively affected by the other feature. In other words, we predict interaction between both experimental factors (GM and processing) with respect to the outcome (acceptance) and the possible moderators and mediators (perceived naturalness, healthiness, necessity and tastiness).

\section{Processing versus technology}

First as a manipulation check in view of the possible floor effect in the pilot study, we examined whether the selected conventional processed food products were perceived as natural and healthy. As Table 1 shows, the perceived naturalness and perceived healthiness of the conventional processed products are both above the midpoint of the 5-point Likert scale.

Table 1.

Means and standard deviations of acceptance and the perceived naturalness, healthiness, necessity and tastiness of nonprocessed, processed, nonprocessed GM and processed GM products

\begin{tabular}{|c|c|c|c|c|c|c|c|c|c|c|c|}
\hline & & \multicolumn{2}{|c|}{ Acceptance } & \multicolumn{2}{|c|}{ Naturalness } & \multicolumn{2}{|c|}{ Healthiness } & \multicolumn{2}{|c|}{ Necessity } & \multicolumn{2}{|c|}{ Tastiness } \\
\hline & & $M$ & $S D$ & $M$ & $S D$ & $M$ & $S D$ & $M$ & $S D$ & $M$ & $S D$ \\
\hline Non- & Non-processed & & & & & & & & & & \\
\hline GM & & 4.26 & 0.80 & 4.44 & 0.76 & 4.57 & 0.72 & 4.07 & 0.96 & 4.30 & 0.80 \\
\hline & Processed & 3.49 & 1.03 & 3.43 & 1.02 & 3.67 & 1.01 & 2.91 & 1.12 & 3.87 & 1.13 \\
\hline \multicolumn{12}{|l|}{ GM } \\
\hline & Non-processed & 2.14 & 1.19 & 1.90 & 1.10 & 2.35 & 1.28 & 1.89 & 1.09 & 2.61 & 1.24 \\
\hline & Processed & 2.37 & 1.05 & 1.84 & 1.02 & 2.20 & 1.23 & 1.81 & 0.99 & 2.52 & 1.20 \\
\hline
\end{tabular}

Note. All simple effects were significant $(p<0.05)$ except for tastiness (GM nonprocessed versus GM processed).

Because all five dependent variables (the evaluation attributes) were measured on the same five-point scale and thereby commensurate, we used a 2(technology: GM versus nonGM) x 2 (processing: processed versus nonprocessed products) x 5 (outcome: acceptance, naturalness, healthiness, necessity, tastiness) within-subject ANOVA to test whether experimental effects varied between dependent variables or not. We found highly significant $(p<0.001)$ interactions of technology, processing and technology x processing with outcome, implying that experimental effects varied between dependent variables. Although a scale and a factor analysis suggested that the five evaluation attributes might be treated as different indicators of a common underlying construct (acceptance), this significant interaction effect of the threeway ANOVA indicates that it is plausible that interaction between technology and processing differs between evaluation attributes. Therefore, we next ran a 2 (technology) x 2 (processing) within-subject ANOVA per dependent variable, starting with the primary outcome, acceptance. This analysis showed a main effect for technology and a main effect for processing (see Table 2). 
Table 2.

Main and interaction effects of technology and processing on acceptance, perceived naturalness, perceived healthiness, perceived necessity and perceived taste $(N=103)$

\begin{tabular}{lccccc}
\hline & Acceptance & Naturalness & Healthiness & Necessity & \multicolumn{2}{c}{ Tastiness } \\
\hline Technology (T) & $F$ & $F$ & $F$ & $F$ & $F$ \\
Processing (P) & $231^{* *}$ & $318^{* *}$ & $239^{* *}$ & $232^{* *}$ & $156^{* *}$ \\
T X P & $13^{*}$ & $60^{* *}$ & $53^{* *}$ & $74^{* *}$ & $12^{*}$ \\
\hline
\end{tabular}

Note. $\mathrm{df}=1,102 ;{ }^{*} p<0.01 . * * p<0.001$.

Participants appeared to accept conventional products more than GM products and to accept nonprocessed products more than processed products (for means see Table 1). The interaction between technology and processing was also significant (see Table 2), implying that the main effects of GM and processing are averages of so-called simple effects and that these simple effects must be tested. Testing simple effects, that is, effects of GM for nonprocessed and for processed food separately, showed that the difference in acceptance of conventional and GM products is greater when it concerned nonprocessed products than when it concerned processed products. Likewise, simple effects tests showed the difference in acceptance between nonprocessed and processed products is greater when it concerned conventional products than when it concerned GM products (for means see Table 1). This suggests that the extent to which GM or processing affect the acceptance of a product depends on whether it is negatively affected by the other feature.

We used the same $2 \times 2$ within-subject ANOVA to test for the effects of technology and processing on each evaluation attribute (perceived naturalness, healthiness, necessity and tastiness). The analyses showed a main effect of technology and a main effect of processing for acceptance, perceived naturalness, perceived healthiness, perceived necessity and perceived tastefulness (see Table 2). Participants appeared to accept conventional products and nonprocessed products more and perceive them as more natural, healthy, necessary and tasty than GM and processed products respectively (for means see Table 1). The interaction between technology and processing was also significant, implying that the main effects are averages of simple effects. Testing simple effects showed that the differences in acceptance, perceived naturalness, healthiness, necessity and tastiness of conventional and GM products were greater for nonprocessed products than for processed products. Also, the effect of processing was smaller for GM than for non-GM products (for means see Table 1). GM and processing both affected the evaluation and acceptance of foods in a non-additive way as there was again interaction. The acceptance and evaluation of a product were affected by GM more strongly for nonprocessed than for processed products and the acceptance and evaluation were affected by processing more strongly for non-GM than for GM products.

\section{Moderation and mediation}

As mentioned in the introduction, evaluations of different product attributes (perceived healthiness, naturalness, necessity and tastiness) are used to explain why GM products are less well accepted than their conventional counterparts. We aimed to investigate whether these product attribute evaluations moderate or mediate the relation between GM and product acceptance and the relation between processing and product acceptance. 
First we will explain the three conditions that must be satisfied for mediation to occur, followed by how to measure moderation and mediation in a within subjects design. Following Baron and Kenny (1986), mediation implies that (1) the experimental factor affects the outcome "product acceptance" and (2) the experimental factor affects the mediator and (3) the mediator affects the outcome, adjusted for the experimental factor. Two remarks on this procedure must be made before going on, however. First, as MacKinnon et al. (2002) showed, the test of criterion (1) has low power if there is complete mediation, because the total experimental effect on the outcome is then the product of the two effects on which criteria (2) and (3) are based. Second, our design allows us to test whether the assumed mediators predict product acceptance, but not whether they causally affect acceptance. Mediation in our within-subject design was tested following the method of Judd, Kenny and McClelland (2001), of which the technical details are given in the appendix on page 59 and 60 of this dissertation. This method also allows a prior test of moderation of experimental effects by the assumed mediator.

Table 3.

Total effect (= simple effect of technology or processing on acceptance) $=$ Direct effect + mediated effect (mediated effect $=$ technology or processing effect on the mediator (simple effects) * mediator effect on acceptance)

\begin{tabular}{llllll}
\hline Predicted effect & & $\begin{array}{l}\text { Technology effect } \\
\text { Nonprocessed } \\
\text { products }\end{array}$ & $\begin{array}{l}\text { Technology } \\
\text { effect Processed } \\
\text { products }\end{array}$ & $\begin{array}{l}\text { Processing } \\
\text { effect Non-GM } \\
\text { products }\end{array}$ & $\begin{array}{l}\text { Processing } \\
\text { effect GM } \\
\text { products }\end{array}$ \\
\hline Simple effects & Naturalness & $-2.55^{* * *}$ & $-1.59 * * *$ & $-1.01 * * *$ & -0.05 \\
& Healthiness & $-2.22 * * *$ & $-1.47 * * *$ & $-0.90 * * *$ & $-0.15^{*}$ \\
& Necessity & $-2.18^{* * *}$ & $-1.10^{* *}$ & $-1.17 * * *$ & -0.08 \\
& Tastiness & $-1.69 * * *$ & $-1.35^{* * *}$ & $-0.43 * * *$ & -0.08 \\
\hline Mediator effects & & & & & 0.18 \\
on acceptance & Naturalness & $0.22^{*}$ & $0.19 * * *$ & 0.11 & $0.25 * *$ \\
& Healthiness & $0.24 * *$ & 0.14 & $0.22 * * *$ & $0.21 *$ \\
& Necessity & $0.34 * * *$ & $0.23 * * *$ & $0.31 * * *$ & $0.39 * * *$ \\
\hline Direct effect & Tastiness & $0.25 * * *$ & $0.23 * * *$ & 0.71 & 0.55 \\
\hline Total effect & Adj. R square & 0.67 & 0.65 & -0.12 & $-0.13 * * *$ \\
\hline
\end{tabular}

${ }^{*} p<0.05 . * * p<0.01 . * * * p<0.001$.

Because of the interaction effect of processing and technology on acceptance (see Table 2), we investigated mediation of the effect of technology on acceptance separately for processed and nonprocessed products, and mediation of the effect of processing on acceptance separately for GM and non-GM products. So the Baron and Kenny (1986) procedure as adapted to within-subject designs by Judd, Kenny and McClelland (2001) was carried out four times in total. Results are shown in Table 3.

Moderation. To test whether the four evaluation attributes (perceived naturalness, healthiness, necessity and tastiness) moderate the effects of GM (yes/no) and processing (yes/no) on acceptance we applied the model in Equation (5) (see appendix) four times (technology effect on acceptance of nonprocessed products, technology effect on 
acceptance of processed products, processing effect on acceptance of non-GM products and processing effect on acceptance of GM). Each time all 4 potential moderators were included (perceived naturalness, healthiness, necessity and tastiness) following model (5). We found no significant moderation of an experimental effect by any of the four mediators in any of the four analyses (GM effect for nonprocessed products, GM effect for processed products, processing effect for non-GM products and processing effect for GM products), all $p>0.05$. Mediation was therefore evaluated using equation (7) in the appendix.

Mediation. To test whether the four evaluation attributes (perceived naturalness, healthiness, necessity and tastiness) mediate the effects of GM (yes/no) and processing (yes/no) on acceptance we applied the model in Equation (7) four times (technology effect for the acceptance of nonprocessed products, technology effect for the acceptance of processed products, processing effect for the acceptance of non-GM products and processing effect for the acceptance of GM products). Each time all 4 potential mediators were included (perceived naturalness, healthiness, necessity and tastiness).

Total, mediated and direct effects. Table 3 shows the direct, mediated and total effects of GM for nonprocessed and processed products and the effects of processing for non-GM and GM products. By investigating these effects we can determine whether mediated GM effects depend on whether the product was processed or not and whether mediated processing effects depend on whether the product was genetically modified or not.

Technology effect for nonprocessed products. We found a significant effect of all four evaluation attributes (M) on acceptance and the direct effect of GM on acceptance was close to zero and not significant (see equation (7) in appendix). This suggests that the four predictive evaluation attributes mediated almost the entire effect (complete mediation) of GM on the acceptance of nonprocessed products (for the direct effect and the effects of the mediators see Table 3).

Technology effect for processed products. We found a significant effect of perceived naturalness, necessity and tastiness on acceptance. The direct effect was not significant and close to zero. This suggests that the three predictive evaluation attributes mediated almost the entire effect (complete mediation) of GM on the acceptance of not-processed products (for all effects, see Table 3).

Technology effect for nonprocesssed versus for processed products. The difference between total and direct technology effect on acceptance is much larger for nonprocessed than for processed products (see bottom of Table 3). This can be explained by the effect of technology on the mediators, which is greater for unprocessed products compared to processed products (see upper half of Table 3). It can be concluded that the total and mediated effect of technology on acceptance are both larger for nonprocessed than for processed products.

Processing effect for non-GM products. We found a significant effect of healthiness, necessity and tastiness on acceptance and the direct effect was close to zero and not significant (see equation (7) in appendix). This suggests that these three predictive evaluation attributes mediated almost the entire effect (complete mediation) of processing on the acceptance of not-GM products (for all effects, see Table 3).

Processing effect for GM products. We found a significant effect of perceived healthiness, necessity and tastiness on acceptance. The direct effect was significant. This suggests that the three predictive evaluation attributes partly mediated the effect of processing on the acceptance of GM products. The rest of the mediated effect is due to the direct effect (See table 3). 
Processing effect for non-GM versus for GM products. The difference between total and direct processing effect on acceptance is much larger for non-GM than for GM products (see bottom of Table 3). This can be explained by the effect of processing on the mediators, which is greater for non-GM products compared to GM products (see upper half of Table 3). It can be concluded that the effect of processing on acceptance is more strongly mediated by perceived naturalness, healthiness, necessity and tastiness when it concerns non-GM products than when it concerns GM products.

We found no moderation of effects of technology or processing on acceptance by naturalness, necessity, healthiness or tastiness. We also found that about all the evaluation attributes contribute to mediation of GM effects for nonprocessed and processed products and of processing effects for non-GM and GM products. However, the interpretation of naturalness, healthiness, necessity and tastiness as mediators is tentative because our design does not allow causal inferences between these five variables. Scale and factor analysis suggested that these five dependent variables might also be treated as different indicators of a common underlying construct, such as a general attitude towards the product.

\section{Discussion}

In the study presented, we investigated the extent to which genetic modification and processing affect acceptance. Besides this we investigated whether the evaluation attributes moderate or mediate GM and processing effects on product acceptance.

This study showed that GM and processing are both factors that affect the evaluation and acceptance of products. The extent to which GM or processing affects the evaluation and acceptance of a product depends on whether the product is negatively affected by the other technology and is furthermore not the result of a floor effect.

The current study also showed that acceptance of 'natural' products will become affected by processing or GM because the acceptance of these unchanged products is suggested to be for a great part mediated by the evaluation attributes. In contrast, the acceptance of products that are already changed in one technology (either GM or processing) are suggested to be less strongly mediated by these evaluation attributes.

We agree with Gamble et al. (2000) that genetic modification differs between product categories because it is a feature that affects the evaluation of products. We do not agree with the authors' suggestion that when products (e.g. chocolate biscuits) are already seen as unhealthy, consumers are indifferent to whether the production technology is also regarded as unhealthy. The results of Gamble et al. (2000) can be better explained by taking the processing of products into account, which appears to be an additional feature that affects the evaluation and acceptance of products. Besides this, we showed that when processed products are perceived as healthy, they are still less affected by GM compared to nonprocessed products. A possible explanation is that the evaluation of the chocolate biscuits was already affected by processing, with the result that the used production technology (GM) affected the evaluation of this processed product less compared to when the product was not processed.

A limitation of this study is that our causal model assumed that necessity, naturalness, health and tastiness affect acceptance, but not each other and that acceptance does not affect any of these four attributes. The more complicated model including these interdependencies can itself not be tested with the current data, only the size and significance of the effects it assumes could be tested. Although scale and factor analysis suggested that the five 
evaluation attributes might also be treated as different indicators of a common underlying construct (acceptance), literature and the significant interaction effect of the three-way ANOVA indicate that it is plausible that interaction between technology and processing differs between evaluation attributes. As mentioned in the introduction, different studies (Gamble et all, 2002; Frewer et al., 1996; Tenbült et al., 2005; Rozin, Spranca, Krieger, Neuhaus, Sunllo, Swerdlin \& Wood, 2004, MAPP annual report, 2000) use different evaluation attributes to explain why GM products are less well accepted than their conventional counterparts. Whether or not different evaluation attributes measure the same underlying construct could be interesting for generalizing results. Future research could therefore focus on whether different evaluation attributes measure the same underlying construct or whether they are conceptually different.

Another limitation is that we only used a limited number of products and that the products were always first presented in the non-GM form and later in the GM form. It is possible that this fixed order could have led to a bias, but we did randomize the order of the nonprocessed and processed products. Besides this, we replicated the findings of our pilot study with a different set of products and with non-student consumers.

Future research could also focus on whether other product features affect the evaluation and acceptance of products, for example whether the product is vegetable or animal. Besides this, benefits that are created by new technologies (e.g. health benefits) could also be product features that affect the evaluation and acceptance of products.

The current study showed that product features such as GM and processing lead to less acceptance of a product, which is associated with more negative evaluations of important product attributes such as the perceived healthiness, naturalness, necessity and tastiness. These effects however are not additive, as the effect of GM on acceptance and evaluation is larger for nonprocessed than for processed products and the effect of processing is larger for non-GM than for GM products.

\section{Appendix}

The mediation model assumes a three-variable system (Baron \& Kenny, 1986). It consists of three causal paths:

1. The direct effect of independent variable on outcome, adjusted for the mediator (path $c$ )

2. The effect of mediator on outcome, adjusted for the independent variable (path $b$ )

3. The effect of independent variable on mediator (path $a$ ).

The total effect of the independent variable is the sum of two effects: the direct effect $(c)$ plus the indirect or mediated effect $(a \times b)$, and is obtained by regressing outcome on independent variable without adjusting for the mediator. To test for mediation, we need three regression analyses according to Baron and Kenny (1986). First, the mediator has to be regressed on the independent variable (with $\alpha 1$ denoting path $a$ of the mediated effect):

$\mathrm{M}=\alpha_{0}+\alpha_{1} \mathrm{X}$

Secondly, the dependent variable has to be regressed on the independent variable (with $\delta_{1}$ denoting the total effect):

$\mathrm{Y}=\delta_{0}+\delta_{1} \mathrm{X}$

Third, the dependent variable has to be regressed on both the independent variable and on the mediator, with $\beta_{1}$ denoting the direct effect (path $c$ ) and $\beta_{2}$ denoting path $b$ of the mediated effect: 
The total effect is equal to the direct effect + mediated effect, that is,

$\delta_{1}=\beta_{1}+\alpha_{1} * \beta_{2}$

To conclude that there is mediation, both $\alpha_{1}$ and $\beta_{2}$ must be unequal to zero, in which case the direct effect $\beta_{1}$ is unequal to the total effect $\delta_{1}$ (partial mediation). In case of full mediation, $\beta_{1}$ is equal to zero. Note that models (1), (2) and (3) are partly within-subject regression models, since $\mathrm{X}$ varies within subjects and $\mathrm{Y}$ and $\mathrm{M}$ vary within and between subjects. This calls for an adaptation of the Baron and Kenny procedure to within-subject designs.

Following the procedure in Judd, Kenny and McClelland (2001) for mediation and moderation analysis in within-subjects designs, we tested for mediation and moderation (of technology or processing effects on acceptance by each potential mediator/moderator) by regression of differences in acceptance (between conditions) on differences in mediators (between conditions). The starting point for this is model (3) for the regression of acceptance (Y) on GM (X) and mediator (M). Model (3) assumes no moderation of the GM effect on acceptance by the mediator $\mathrm{M}$. To test for moderation, we extended (3) as follows: $Y_{i j}=\beta_{0}+\beta_{1} X_{j}+\beta_{2} M_{i j}+\beta_{3} X_{j} M_{i j}$

where $Y_{i j}$ is acceptance by person $i$ in $G M$ condition $j(j=1$ means $G M, j=0$ means not-GM) and $X_{j}$ is coded as: $G M=1$; not-GM $=-1$. In terms of equation (5), moderation occurs if $\beta_{3}$ is unequal to zero. If $\beta_{3}=0$, then (5) reduces to (3). To see how this model can be applied to within-subject designs, we need the following steps:

When $\mathrm{X}=1(\mathrm{GM})$, the model is:

$\mathrm{Y}_{\mathrm{i} 1}=\left(\beta_{0}+\beta_{1}\right)+\left(\beta_{2}+\beta_{3}\right) \mathrm{M}_{\mathrm{i} 1}$

When $\mathrm{X}=-1$ (not-GM), the model is:

$\mathrm{Y}_{\mathrm{i} 0}=\left(\beta_{0}-\beta_{1}\right)+\left(\beta_{2}-\beta_{3}\right) \mathrm{M}_{\mathrm{i} 0}$

So the within-subject difference in acceptance between GM and not-GM is:

$\Delta \mathrm{Y}_{\mathrm{i}}=\mathrm{Y}_{\mathrm{i} 1}-\mathrm{Y}_{\mathrm{i} 0}$

$\Delta \mathrm{Y}_{\mathrm{i}}=\left(2 \beta_{1}\right)+\beta_{2}\left(\mathrm{M}_{\mathrm{i} 1}-\mathrm{M}_{\mathrm{i} 0}\right)+\beta_{3}\left(\mathrm{M}_{\mathrm{i} 1}+\mathrm{M}_{\mathrm{i} 0}\right)$

which shows that:

1. $M$ is a moderator of the GM effect on acceptance if the sum $\left(M_{i 1}+M_{i 0}\right)$ is predictive of the difference in acceptance between GM and not-GM.

2. Assuming absence of moderation (i.e. $\beta_{3}=0$ ), $M$ is a mediator of the $G M$ effect on acceptance if the difference $\left(\mathrm{M}_{\mathrm{i} 1}-\mathrm{M}_{\mathrm{i} 0}\right)$ is predictive of the difference in acceptance between GM and not-GM.

3. Assuming absence of moderation $\left(\beta_{3}=0\right)$ the intercept $2 \beta_{1}$ of the regression in (6) is the direct effect of GM versus not-GM on acceptance, see equation (3).

We therefore regressed the difference in acceptance between GM and not-GM on both the $\mathrm{M}$ difference and the $\mathrm{M}$ sum (equation 6), including into (6) all four potential mediators (naturalness, healthiness, necessity, tastiness) at the same time.

Because none of the four attributes significantly moderated the technology effect either for nonprocessed or for processed products and none moderated the processing effect either for GM or for non-GM products, it can be concluded that $\beta_{3}=0$ for each attribute in each of the four simple effects analyses and therefore:

$\Delta \mathrm{Y}_{\mathrm{i}}=\left(2 \beta_{1}\right)+\beta_{2}\left(\mathrm{M}_{\mathrm{i} 1}-\mathrm{M}_{\mathrm{i} 0}\right)$

$\Delta \mathrm{Y}_{\mathrm{i}}=$ total effect, $\left(2 \beta_{1}\right)=$ direct effect, $\beta_{2}\left(\mathrm{M}_{\mathrm{i} 1}-\mathrm{M}_{\mathrm{i} 0}\right)=$ mediated effect

(note that the mean of $M_{1}-M_{0}$ across all subjects estimates $\alpha_{1}$ in equation (1)). 
Chapter 6

General discussion 
The main aim of the research presented in this thesis is to understand the mechanisms underlying people's reactions towards modern food technologies and food products. In this thesis we investigated which processing and evaluation strategies are used when people are confronted with familiar and non-familiar food products. Moreover, by understanding how these evaluations are formed, one can better predict how consumer evaluations of food products will evolve and consequently the future success of those food innovations. We aimed to investigate which processing and evaluation strategies are used when people are confronted with novel and more familiar food products. Furthermore, we tried to provide more insight into why novel and more familiar food products are differently evaluated, not only related to interpersonal differences (attitude strength), but also related to product characteristics. In this final chapter, the main empirical findings presented in Chapters 2 to 5 will be summarized. Subsequently, these findings will be discussed in a broader context and suggestions for future research will be provided.

\section{Overview of the main findings}

The first central question in this dissertation was whether food technologies differ in familiarity and in evaluation. The pilot study presented in Chapter 2 investigated five new food categories (genetic modification (GM), functional food production, organic production (OP), food supplements and vegetarian food production). Not only seemed GM and OP initially and intuitively to be contrasting, results showed that GM and OP received the most extreme judgements. GM is the food technology that is least well familiar to the public and is both implicitly and explicitly less appreciated than organic production (OP). Moreover, people have the most negative first impression towards GM and are most ambivalent towards this technology. This pattern is reversed for OP; people have the most positive attitude towards OP and people are least ambivalent towards this food technology. Functional food production, food supplements and vegetarian production are equally accepted and are perceived as (slightly) positive. The main study of Chapter 2 investigated the attitude, familiarity, first impression and ambivalence towards GM and OP and found similar results. In addition, Chapter 4 supported these findings by showing that consumers perceive themselves as less knowledgeable about GM than about OP and by showing that consumers have a less positive attitude and are more ambivalent towards GM than towards OP. In sum, it appears that food technologies indeed differ in familiarity and in how positively they are evaluated. Since GM and OP received the most extreme judgements, we chose to use these two technologies in our further research.

The second central question in this dissertation was whether a relationship could be found between the familiarity of food technologies and attitude strength. Chapter 2 showed that people have a stronger attitude (more central, more committed and less ambivalent) towards a relatively familiar food technology (OP) than towards a relatively novel technology (GM). Moreover, Chapter 2 showed a positive correlation between the familiarity of a food technology and the attitude strength towards a food technology. Both results are supported in Chapter 4 and show that attitudes are stronger when people are more knowledgeable about a food technology (either GM or OP). Furthermore, Chapter 2 showed that attitude strength moderates the relationship between implicit and explicit attitudes: when attitudes are strong (e.g. OP) there is a positive relation between implicit and explicit attitudes but such a relation is absent in case of weak attitudes (e.g. GM). When correlations between explicit and implicit attitudes are high, they are believed to be highly 
predictive of behaviour (Spence \& Townsend, 2006). Therefore people's attitude towards OP is suggested to be strong and therefore suggested to be highly predictive for behaviour. In contrast, when correlations between explicit and implicit attitudes are low, they are believed to be less predictive of actual behaviour and are believed to be due to a lack of introspective access to implicitly assessed representations (Hofmann et al., 2005). This suggests that people do not have a strong attitude towards GM and that the attitude towards GM is not well embedded in people's inter- and intra-attitudinal structure. Therefore the attitude towards GM is assumed to be not easily accessible and not predictive of behaviour. The results of Chapter 2 are interpreted to indicate that people's evaluation towards a relatively familiar food technology is a relatively automatic process, while the evaluation towards a relatively novel food technology is assumed to be an analytical process.

The third central question of this dissertation was whether there is a difference in the process by which novel and familiar food products are evaluated (analytical versus automatic). As mentioned above, Chapter 2 suggested that people can infer their opinion towards familiar food technologies more automatically than towards less familiar food technologies. Chapter 3 showed in two studies that different processing strategies (analytical versus automatic) are used to judge products that are labelled as either GM or not GM. GM labelling of foods is interpreted to induce analytical processing of information, whereas not labelling as GM is interpreted to induce automatic processing. Furthermore, it was predicted that non-verifiable food characteristics are used when categorizing GM products, whereas more verifiable food characteristics are used when categorizing non-GM foods. Chapter 3 showed that verifiable food characteristics (e.g. whether the product is processed or not) are used to categorize GM products, whereas nonverifiable food characteristics (e.g. whether the product is healthy or not) are used to categorize products not labelled as GM.

Since Chapter 2 and Chapter 4 showed that GM is a relatively novel food technology, these results suggest that a category that represents these novel GM products is not readily available. Consequently, people cannot infer information automatically and have to search their memory (analytically) for verifiable information at the concrete level in order to generalize information from the exemplars. In contrast, the results of Chapter 3 are interpreted to mean that when products are not labelled as GM, (non-verifiable) information is automatically derived from the superordinate level and used to evaluate that product.

The fourth central question was whether different evaluation strategies (product-based versus process-based) are used when consumers evaluate food products that are manufactured with the use of novel versus familiar food technologies. Chapter 4 suggests that the evaluation of food products is product specific. We can tentatively suggest that benefits (i.e. the specific advantages that are brought to a product through a technology) were considered in consumers' evaluations when it concerned GM food products. In contrast, benefits were not considered when consumers had to evaluate OP food products. Although Chapter 4 remains inconclusive as to whether this difference is related to differences in familiarity, we are tempted to assume that the evaluation of GM is productbased and the evaluation of OP is process-based. As mentioned above, Chapter 3 showed that when consumers are confronted with a relatively new food technology, like GM, they are likely to actively search for verifiable information to base their evaluation on. This analytical processing strategy could explain why the benefits are only considered in the evaluation when it concerned GM. Therefore it could be argued that the evaluation of GM is product-based. It must be noted that the used benefits in Chapter 4 are by definition non- 
verifiable benefits (healthy, tasteful). We believe that because this information was given, the benefits themselves can be seen as verifiable information that was analytically searched for. In contrast, Chapter 3 showed that consumers are likely to use an automatic processing strategy when they are confronted with a relatively familiar technology (like OP). Therefore it may be argued that the evaluation of OP is mainly based on general judgments (processbased).

The fifth central question was why the evaluation of food products might be product specific. Chapter 4 provided some, but inconclusive, evidence that the use of different evaluation strategies (process-based versus product-based) is related to consumers' attitude strength. As mentioned above, Chapter 2 and 4 showed that consumers have a relatively strong attitude towards familiar food technologies (e.g. OP) and a relatively weak attitude towards novel food technologies (e.g. GM). In addition, Chapter 4 suggests that productbased evaluation strategies are used when attitudes towards a technology are in general weak (GM) and that evaluations are process-based when attitudes towards a technology are in general strong (OP). Unfortunately the results of Chapter 4 did not show that different evaluation strategies are used when consumers differ in attitude strength within one technology (either GM or OP). Therefore these results can also be due to other differences between GM and OP. Chapter 5 also tried to shed some light on why the evaluation of novel food products might be product specific. Chapter 5 showed that food characteristics can provide some insight into why consumers accept food products to different extents. It appeared that food characteristics, such as whether a product is genetically modified or not and whether a product is processed or not, are two important features that influence the acceptance and evaluation of those products. More specifically, the extent to which the evaluation and acceptance of a product are affected by genetic modification or processing depends on whether the evaluation of the product is negatively affected by the other technology: The evaluation of natural products (e.g. non-GM products or non-processed products) are more affected by change than the evaluation of already unnatural products (e.g. GM products or processed products). Furthermore, non-verifiable evaluation attributes (perceived healthiness, naturalness, necessity and tastiness) appear to mediate these effects. When unchanged ('natural') products become affected once by either GM or processing, the acceptance of the changed product is mediated largely by the non-verifiable evaluation attributes. In contrast, when products are changed twice (when processed products are also genetically modified or vice versa), the acceptance of the twofold changed product appears to be less strongly mediated by these non-verifiable evaluation attributes.

\section{Limitations and further research}

\section{Food technologies}

A limitation of the research described in this thesis is that it could be debated whether GM is a fairly novel food technology and whether OP is a relatively familiar food technology. Chapter 2 and Chapter 4 showed that the level of subjective knowledge about OP is around the midpoint of a 5-point Likert scale. Because in both chapters this is significantly higher than the level of subjective knowledge towards GM, we concluded that OP is a relatively familiar technology.

Another limitation of the research described in this dissertation is that we investigated only a limited number of food technologies. Chapter 2 showed that GM and OP received the most extreme judgements (out of genetic modification, functional food production, 
organic food production, food supplements and vegetarian food production). Therefore Chapters 2 and 4 investigated GM versus OP and Chapters 3 and 5 GM versus not GM (the latter implies a conventional food technology). This small number of food technologies could limit the ability to generalize the findings to other food technologies. However the attitudes towards GM and OP varied from negative/neutral to positive and the attitude strength varied from weak/moderate to strong. We therefore argue that the results of our studies can be generalized to other issues within the same valence and attitude strength ranges. Nevertheless, due to the natural correlation or confound between technology and attitude characteristics (strengths, valence), we have to be cautious in interpreting our results. Further research towards other food issues can provide insight into the process how an attitude evolves when a technology becomes better known. Another possibility would be to repeat the studies described in this dissertation over time. GM can become a more familiar food technology in future, with the result that consumers' attitude towards this technology will become stronger. Consequently it can be suggested that the evaluation of this technology will become more process-based and more automatically processed.

\section{Design}

Another limitation of the research described is that we told our participants to imagine the products in our experiments; we did not present real products. It could be that the product characteristics that were tested in our studies do not similarly influence product evaluations in real life. In real life, products may be evaluated in a more holistic way and therefore their evaluation could be affected by multiple factors at the same time. It would be interesting to investigate whether the same food characteristics found in the studies of this dissertation have a similar influence on acceptance in real life. Likewise it would be interesting to investigate whether other food characteristics affect the evaluation of food technologies in real life (for example, whether a product is vegetable or animal). This could provide more insight into the factors that influence acceptance of (novel) food technologies. A way to investigate this is to conduct experiments in a real supermarket, or by conducting experiments in a laboratory that imitates a supermarket.

\section{Results}

A further issue is whether analytical processing can be seen as equivalent to a productbased evaluation strategy and whether automatic processing is equivalent to a processbased evaluation strategy. Although the studies presented in this dissertation suggest that this is the case, we must be cautious in interpretations, because it was not directly investigated. Further research could investigate the relationship between these concepts.

Another limitation of the research presented in this dissertation is that we can only tentatively suggest that attitude strength of consumers towards food technologies explains the use of different evaluation strategies (analytical/product-based versus automatic/process-based). Although consumers appeared to include benefits in their evaluation when they had a weak attitude towards a certain food technology and appeared not to involve benefits in their evaluation when they had a strong attitude towards a food technology, we could not find evidence that different evaluation strategies are used when consumers differ in attitude strength within one technology (either GM or OP). Further research could focus on why this interpersonal effect is only present between food technologies and not within. 
Furthermore, Chapter 5 showed that the acceptance of products that are changed once (conventional products that become either GM or processed) seem more strongly mediated by non-verifiable product characteristics than when products were changed twice (when processed products become genetically modified or vice versa). It could be argued that this difference in mediation can be explained by the extent of automatic versus analytical processing. Chapter 3 showed that GM labelling of foods induces in general analytical processing of information and therefore products are classified relatively more often on the basis of verifiable categorization criteria compared to when they were not labelled as GM. Although we acknowledge that in general people process novel food technologies analytically, this does not mean that no automatic processing was present at all or in some participants. Therefore it is plausible that the evaluation of food products is affected by both analytical and automatic processing at the same time and could therefore be influenced by both verifiable (e.g. whether a product is processed or not) and non-verifiable (e.g. whether a product is healthy or not) product characteristics at the same time. Chapter 5 showed that the effect of processing on the acceptance of non-GM products was almost completely mediated by non-verifiable product characteristics. In contrast, the effect of processing on the acceptance of GM products was partly mediated by non-verifiable product characteristics. The latter finding suggests that the acceptance of GM products could be explained by a mediation effect of non-verifiable food characteristics and a significant direct effect of a verifiable (whether the product is processed or not) food characteristic. The presence of both automatic and analytic processing could therefore explain why the evaluation of GM products is mediated by non-verifiable product characteristics to a lesser extent than the evaluation of non-GM products. In contrast, Chapter 5 showed that the effect of technology (GM or not) on acceptance of processed and non-processed products were both almost completely mediated by non-verifiable product characteristics. Although it can be assumed that processed products are relatively familiar products and therefore their evaluation is suggested to be completely mediated by non-verifiable food characteristics, it can not explain why the evaluation of non-processed products is more mediated by non-verifiable product characteristics than the evaluation of processed products. Further research is needed to explain these suggestions.

Despite these limitations, the research presented in this dissertation had particular strengths. People's attitudes towards relatively unknown food technologies can not be validly measured with explicit measurements only because people's attitudes towards these technologies may not readily accessible. Therefore we measured people's attitudes both explicitly and implicitly (with the EAST). Furthermore, we replicated our main results in more than one study. In Chapter 2 and 4 we showed that when people are more familiar with food technologies, their attitudes towards these technologies will become stronger. Moreover, we suggested in Chapter 2 and Chapter 4 and showed in Chapter 3 that novel food technologies are analytically processed. Furthermore, we showed that evaluations of novel food technologies are product specific in Chapter 4 and 5, once related to benefits and once related to processed products. Moreover, we replicated these results with students as well as non student consumers.

\section{Conclusions and implications}

The main aim of the research presented in this dissertation was to understand the mechanisms underlying people's reactions towards food technologies. The first conclusion 
from our findings is that food technologies differ in familiarity and in how positively they are evaluated. It appears that when food technologies become more familiar, attitudes towards these food technologies will become stronger and theoretically they will therefore be harder to change. This implies that it is (still) possible for governments and manufacturers to influence consumers' attitudes towards unfamiliar (food) technologies in either direction (positive or negative). In contrast, it will be difficult for governments and manufacturers to influence consumers' attitudes towards relatively familiar (food) technologies because attitudes towards these product issues are strong and therefore not easily influenced.

Moreover, our findings show that consumers use different processing strategies (analytical versus automatic) when they are confronted with food products. Consumers seem to search analytically for verifiable information when they evaluate unfamiliar food products and search automatically for non-verifiable information when they evaluate familiar food products. In addition, our findings suggest that the information that is retrieved is used in consumers' evaluations of food products when attitudes towards these products are not strong. These findings provide insight for governments and manufacturers into what kind of product information and what kind of (food) products are open to change in order to influence consumers' attitudes. For example, it is much more efficient for manufacturers to invest in product information on labels (or commercials) when consumers have a weak attitude towards a product or concept than when consumers have a strong attitude towards that product or concept.

Furthermore our findings provided some insight into why some (food) products are more positively evaluated by consumers than other (food) products. Although we can only tentatively suggest that interpersonal differences in attitude strength towards food technologies explain the use of different evaluation strategies (analytical/product-based versus automatic/process-based), it can be suggested that the acceptance of novel food technologies is product specific. The findings suggest that several product characteristics (e.g. whether the product is genetically modified, whether the product is manufactured, whether specific advantages that are brought to a product through a technology are mentioned) affect the acceptance of food products and how well they are evaluated. These findings provide insight for governments and manufacturers about when new food products are best accepted by consumers.

Finally, the presented research provided insight into how consumer evaluations of food products are formed over time. It can be suggested that when food technologies become more familiar, more automatic evaluation strategies will be used to evaluate products that are manufactured with the use of these technologies. Also, as long as consumer attitudes towards new food products are not well embedded in their cognitive system, governments and manufacturers have the opportunity to influence consumers evaluations of these food products.

In sum, the research presented in this dissertation provides more insight into the mechanisms underlying the reactions of consumers towards new food products. Not only does this insight help to better understand how new food products are perceived and evaluated, but by understanding how these evaluations are formed, one can better predict how consumer evaluations of food products will evolve and consequently the future success of those food innovations. 
Summary 
The main aim of the research presented in this thesis is to understand mechanisms underlying people's reactions towards modern food technologies. More insight into the mechanisms underlying the reactions of consumers towards these food technologies will help us understand how food products are perceived and evaluated. In this thesis we investigated which processing and evaluation strategies are used when people are confronted with familiar and non-familiar food products. Moreover, by understanding how these evaluations are formed, one can better predict how consumer evaluations of food products will evolve and, consequently, the future success of those food innovations.

In Chapter 2 we investigated whether specific types of food technologies differ in their perceived familiarity and in how positively they are evaluated. In a pilot study, forty-five undergraduate students were asked about their attitude, attitude strength and level of knowledge toward several food technologies (genetic modification (GM), functional food production, organic food production (OP), food supplements and vegetarian food production). Results showed that GM and OP received the most extreme judgements. GM is the food technology that is least well known by the public and is less appreciated than organic production (OP). Moreover, people have the most negative first impression towards GM and are most ambivalent towards this technology. This pattern is reversed for OP; people have the most positive attitude towards OP and people are least ambivalent towards this food technology. Functional food production, food supplements and vegetarian production are equally accepted and are perceived as (slightly) positive. In the main study of Chapter 2 the findings of the pilot study were replicated and we investigated whether a relationship could be found between the familiarity of food technologies and attitude strength. In the main study we used an implicit measurement (EAST) in addition to an explicit questionnaire to investigate people's attitudes and attitude strength towards a relatively novel and a relatively known food technology (respectively genetic modification (GM) and organic production (OP)). We predicted that attitudes are more strong (highly central and highly committed) and less ambivalent when food technologies are better known to the public. We predicted that when a food technology is well known, significant correlations between the implicit and explicit measures will be found. In contrast, we predicted that when a food technology is not well known, significant correlations will not be present. The results showed a positive correlation between the familiarity of a food technology and the attitude strength towards a food technology. Furthermore, Chapter 2 showed that attitude strength moderates the relationship between implicit and explicit attitudes. It appeared that the implicit and explicit attitudes towards a relatively familiar technology (e.g. OP) correlated significantly. When correlations between explicit and implicit attitudes are high, they are believed to be highly predictive of behaviour (Spence \& Townsend, 2006). Therefore people's attitude towards OP is considered to be strong and highly predictive for behaviour. In contrast, Chapter 2 showed that such a correlation between implicit and explicit attitudes was absent towards a relatively novel technology (e.g. GM). When correlations between explicit and implicit attitudes are low, they are believed to be less predictive of actual behaviour and are believed to be due to a lack of introspective access to implicitly assessed representations (Hofmann et al., 2005). This suggests that people do not have a strong attitude towards GM and that the attitude towards GM is not well embedded in people's inter- and intra-attitudinal structure. Therefore the attitude towards GM is assumed to be not easily accessible and not predictive of behaviour. The results of Chapter 2 are interpreted to indicate that people's evaluation towards a 
relatively familiar food technology is a relatively automatic process, while the evaluation towards a relatively novel food technology is assumed to be an analytical process.

In Chapter 3, we investigated in two studies whether novel and familiar food products are associated with different processing strategies (analytical versus automatic). In study 3.1 seventy-four non-student consumers were asked to classify a list of food products in two groups. The participants were free to divide the food products into two groups as long as they mentioned why they categorized the two groups as such. Half of the participants were told that it concerned genetically modified products. We predicted that a more analytic processing strategy is used when confronted with food products that are labelled as genetically modified because consumers are not familiar with this food technology. Moreover, we predicted that verifiable food characteristics are used to categorize GM products. Verifiable categorization criteria are empirical and observable observations of the physical characteristics of a stimulus or one's own reactions towards the stimulus (e.g. whether the product is industrially processed or not). In contrast, we predicted that a more automatic processing strategy is used when confronted with food products that are not labelled as GM. Also, we predicted that non-verifiable food characteristics are used when categorizing these products. Non-verifiable categorization criteria are beliefs that cannot be verified or tasted by the consumer (e.g. whether the product is healthy or not). Study 3.1 showed that different processing strategies (analytical versus automatic) are used to judge products that are labelled as either GM or not GM. GM labelling of foods is interpreted to induce analytical processing of information, whereas not labelling as GM is interpreted to induce automatic processing. Furthermore, this study showed that verifiable food characteristics (e.g. whether the product is processed or not) are used to categorize GM products, whereas non-verifiable food characteristics (e.g. whether the product is healthy or not) are used to categorize products not labelled as GM. Study 3.2 tested the same hypothesis, under conditions of differential cognitive load during the performance of the task. One hundred sixty-six undergraduate students had to count backward from 100 to 1 , while they executed the categorization task. It was predicted that when the use of verifiable and non-verifiable classification is associated with a distinction in information processing strategies (analytical versus automatic), inhibiting people's processing capacity would lead to relatively more use of non-verifiable classifications, because of more frequent automatic processing behaviour. The results of study 3.2 showed that cognitive load increased more automatic processing behaviour and therefore it can be tentatively concluded that the results of study 3.1 are due to automatic versus analytic processing. The two studies of chapter 3 showed that (since chapter 2 showed that GM is a relatively novel food technology) a category that represents these novel products is not readily available. Consequently, people cannot infer information automatically and have to search their memory (analytically) for verifiable information at the concrete level in order to generalize information from the exemplars. In contrast, the results of Chapter 3 are interpreted to mean that when products are not labelled as GM, (non-verifiable) information is automatically derived from the superordinate level and used to evaluate that product.

In Chapter 3 we predicted that consumers use different cognitive processing strategies (analytic versus automatic) when categorizing food products. In Chapter 4, we investigated whether different evaluation strategies (product-based versus process-based) are used when consumers evaluate food products that are manufactured with the use of novel and (relatively) familiar food technologies. Assuming that product-based evaluation strategies are analytical processes and process-based evaluation strategies relatively automatic 
processes, it can be suggested that product-based evaluations are more likely when food technologies are novel, while process-based evaluations are more involved when food technologies are familiar. In Chapter 4, one hundred and fourteen consumers were asked to evaluate genetically modified (GM) and organically produced (OP) food products in combination with benefits (i.e. specific advantages that are brought to a product through a technology). We predicted that the benefits were considered in consumers' evaluation when it concerned novel food products (product-based). In contrast, we predicted that benefits were not considered when they had to evaluate familiar food products (process-based). Chapter 4 showed that the evaluation of food products is product specific. It appeared that benefits (i.e. the specific advantages that are brought to a product through a technology) were considered in consumers' evaluation when it concerned GM food products. In contrast, benefits were not considered when consumers had to evaluate OP food products. Although Chapter 4 remains inconclusive whether this difference is due to differences in familiarity, it is plausible that the use of these different evaluation strategies is related to consumers' attitude strength towards a (novel or relatively familiar) food technology.

We predicted that when consumers have a relatively weak attitude towards a food technology (GM), they will involve the offered benefits in their evaluation (product-based evaluation strategy) because they analytically search for information. In contrast, we predicted that when consumers have a strong attitude towards a food technology (OP), they will not involve the offered benefits in their evaluation (process-based evaluation strategy) because they will base their evaluation on their (automatic) general opinion. Chapter 4 provided some, but inconclusive, evidence that the use of different evaluation strategies (process-based versus product-based) is related to consumers' attitude strength. Chapter 2 and 4 showed that consumers have a relatively strong attitude towards familiar food technologies (e.g. OP) and a relatively weak attitude towards novel food technologies (e.g. GM). In addition, Chapter 4 suggests that product-based evaluation strategies are used when attitudes towards a technology are in general weak (GM) and processed based when attitudes towards a technology are in general strong (OP)). Unfortunately the results of Chapter 4 did not show that different evaluation strategies are used when consumers differ in attitude strength within one technology (either GM or OP). Therefore it must be noted that these results can be due to other differences between GM and OP.

It can be concluded that these findings provide some insight into why some (food) products are more positively evaluated by consumers than other (food) products. Although we can only tentatively suggest that interpersonal differences in attitude strength towards food technologies explain the use of different evaluation strategies (analytical/productbased versus automatic/process-based), it can be suggested that the evaluation of novel food technologies is product specific.

In Chapter 4 we suggested that the evaluation of food products is product specific. In Chapter 5, we tried to replicate the finding that the evaluation of food products is product specific by showing that the acceptance and evaluation of food products depends on product features such as whether the product is genetically modified or not and whether they are processed food products or not. In a pilot study, thirty-six undergraduate students were asked to evaluate three food products that have a well known non-processed or natural form (e.g. potato) and a well known processed form (e.g. crisps). Moreover, the consumers had to evaluate these products in a GM form (e.g. GM potato and GM crisps). We predicted that whether food products are genetically modified or not and whether they are processed or not are two important features that affect the acceptance of food products and how well 
they are evaluated. The pilot study showed that food characteristics can provide some insight into why consumers accept novel food products to different extents. It appeared that food characteristics, like whether a product is genetically modified or not and whether a product is processed or not, are two important features that influence the acceptance and evaluation of those products. More specifically, the extent to which the evaluation and acceptance of a product are affected by genetic modification or processing depends on whether the evaluation of the product is negatively affected by the other technology: Natural products (e.g. non-GM products or non-processed products) are more affected by change than already unnatural products (e.g. GM products or processed products). In the main study of Chapter 5 we replicated the findings of the pilot study with one hundred and three consumers. Furthermore, we investigated whether certain non-verifiable product attributes (perceived naturalness, healthiness, necessity and tastiness) influence the effects of genetic modification and processing on acceptance. The results showed that nonverifiable evaluation attributes (perceived healthiness, naturalness, necessity and tastiness) appeared to mediate these effects. When unchanged ('natural') products become affected once by either GM or processing, it appears that the acceptance of the changed product is mediated largely by the non-verifiable evaluation attributes. In contrast, when products are changed twice (when processed products become genetically modified or vice versa), the acceptance of the twofold changed product appears to be less strongly mediated by these non-verifiable evaluation attributes.

It can be concluded that chapter 4 and 5 both suggest that the acceptance of food technologies is product specific. The findings suggest that several product characteristics (e.g. whether the product is genetically modified, whether the product is manufactured, whether specific advantages that are brought to a product through a technology are mentioned) affect the acceptance of food products and how well they are evaluated.

In sum, the research presented in this dissertation provided more insight into the mechanisms underlying the reactions of consumers towards food products. Not only does this insight help to better understand how food products are perceived and evaluated, but by understanding how these evaluations are formed, one can better predict how consumer evaluations of food products will evolve and consequently the future success of those food innovations. 
Nederlandse Samenvatting 
Het onderzoek dat in dit proefschrift beschreven is heeft als doel inzicht te krijgen in hoe mensen tot een oordeel komen wanneer ze geconfronteerd worden met moderne voedingstechnologieën. Als men meer inzicht heeft in dit mechanisme weten we beter hoe nieuwe voedingsproducten gepercipieerd en geëvalueerd worden. In dit proefschrift onderzoeken we welke verwerkingstrategieën en evaluatiestrategieën gebruikt worden wanneer mensen geconfronteerd worden met bekende en minder bekende voedingsproducten. Uit kennis over hoe evaluaties gevormd worden kan meer inzicht voortkomen over hoe deze evaluaties door de tijd heen evolueren.

In hoofdstuk 2 onderzochten we of specifieke voedingstechnologieën verschillen in hun waargenomen bekendheid en in de mate waarin ze als positief geëvalueerd worden. In een pilot studie werd aan vijfenveertig studenten gevraagd naar hun attitude, attitudesterkte en de mate van kennis ten opzichte van verschillende voedingstechnologieën (genetisch gemodificeerde voeding, functionele voeding, biologische voeding, voedingsupplementen en vegetarische voeding). De resultaten van deze studie lieten zien dat men het minst bekend is met genetische modificatie en dat deze het minst gewaardeerd wordt. Daarnaast lieten de resultaten zien dat mensen de meest negatieve eerste indruk hebben van genetische modificatie en dat ze ook het meest ambivalent zijn tegenover deze technologie. Tegenovergestelde resultaten werden er gevonden voor biologische voeding; mensen hebben de meest positieve attitude en staan het minst ambivalent tegenover deze technologie. Functionele voeding, voedingsupplementen en vegetarische voeding worden in gelijke mate geaccepteerd en worden (licht) positief geëvalueerd. In het hoofdonderzoek van hoofdstuk 2 werden deze resultaten gerepliceerd en werd verder onderzocht of er een relatie bestaat tussen de bekendheid van voedingstechnologieën en attitudesterkte. In deze studie werd een impliciete maat (EAST) gebruikt naast een expliciete vragenlijst om de attitude en attitudesterkte van consumenten te meten ten opzichte van een bekende (biologische voeding) en een minder bekende (genetische modificatie) voedingstechnologie. We voorspelden dat attitudes sterker zijn (hoog centraal en hoog betrokken) en minder ambivalent wanneer voedingstechnologieën beter bekend zijn bij het publiek. We voorspelden verder dat wanneer een voedingstechnologie bekend is, er significantie correlaties bestaan tussen de impliciete en expliciete meting. Aan de andere kant voorspelden we dat een dergelijke correlatie niet aanwezig is wanneer een voedingstechnologie minder bekend is. De resultaten lieten zien dat er inderdaad een positieve correlatie is tussen de bekendheid van een voedingstechnologie en attitudesterkte. Daarnaast liet hoofdstuk 2 zien dat attitudesterkte de relatie tussen impliciete en expliciete attitudes modereert. Het blijkt dat de impliciete en expliciete attitudes ten opzichte van een relatief bekende voedingstechnologie (biologische voeding) significant correleren. Hierdoor wordt de attitude van mensen ten opzichte van biologische voeding gezien als sterk en voorspellend voor gedrag. Aan de andere kant laat hoofdstuk 2 ook zien dat de correlatie tussen de impliciete en expliciete attitude ten opzichte van een nieuwe technologie (genetische modificatie) niet aanwezig is. Dit suggereert dat mensen geen sterke attitude hebben ten opzichte van genetische modificatie en dat deze attitude niet sterk ingebed is in de inter- en intra-attitudinale structuur. Dit heeft als gevolg dat de attitude ten opzichte van genetische modificatie niet gemakkelijk toegankelijk is en niet voorspellend voor gedrag. De resultaten van hoofdstuk 2 kunnen geïnterpreteerd worden als zijnde dat de evaluatie van mensen ten opzichte van een bekende voedingstechnologie een relatief automatisch proces is, terwijl de evaluatie ten opzichte van een minder bekende voedingstechnologie via een meer analytisch proces tot stand komt. 
In hoofdstuk 3 onderzochten we in twee studies of informatie over bekende en minder bekende voedingstechnologieën verschillend verwerkt worden (analytisch versus automatisch). In de eerste studie werd aan vierenzeventig consumenten gevraagd om een lijst van voedingsproducten te categoriseren in twee groepen. De deelnemers waren vrij om de producten te verdelen in twee groepen zolang ze maar vermeldden waarom ze de producten als zodanig verdeelden. Aan de helft van de deelnemers werd verteld dat het om genetisch gemodificeerde producten ging. De andere helft van de deelnemers was in de veronderstelling dat het om conventionele voedingsproducten ging. We voorspelden dat de consumenten een analytische verwerkingsstrategie zouden gebruiken als het om voedingsproducten ging die gelabeld waren als genetisch gemodificeerd aangezien de consumenten minder bekend zijn met deze voedingstechnologie. Daarnaast voorspelden we dat genetisch gemodificeerde producten op basis van verifieerbare kenmerken gecategoriseerd zouden worden (bijvoorbeeld of een product bewerkt is of niet). Aan de andere kant voorspelden we dat conventionele voedingsproducten op basis van niet verifieerbare kenmerken gecategoriseerd zouden worden (bijvoorbeeld of een product gezond is of niet). De studie liet zien dat consumenten inderdaad verschillende verwerkingsstrategieën (analytisch versus automatisch) gebruiken. De resultaten lieten zien dat oordelen over producten die gelabeld zijn als zijnde genetisch gemodificeerd analytisch tot stand komen, terwijl producten die niet als zodanig gelabeld zijn automatisch verwerkt worden. De resultaten lieten verder zien dat verifieerbare kenmerken gebruikt werden om genetisch gemodificeerde voedingsproducten te categoriseren terwijl niet-verifieerbare voedingskarakteristieken gebruikt werden om conventionele producten te categoriseren. De tweede studie repliceerde het onderzoek van de eerste studie maar nu werd er aan de helft van de respondenten gevraagd om van honderd terug naar één te tellen terwijl ze de categorisatietaak uitvoerden. Er werd verwacht dat wanneer het verwerkingsproces geinhibeerd zou worden door het terugtellen, respondenten meer een automatische verwerkingsstrategie zouden gebruiken dan een analytische verwerkingsstrategie. De resultaten lieten zien dat respondenten genetisch gemodificeerde producten inderdaad meer automatisch verwerkten en meer niet-verifieerbare categorisatie criteria gebruikten indien ze terug moesten tellen. Het gebruik van verifieerbare en niet-verifieerbare categorisatiecriteria hangt dus samen met informatieverwerkingsstrategieën (analytisch versus automatisch). Deze twee studies lieten zien dat indien informatie over een nieuwe voedingstechnologie niet beschikbaar is, mensen analytisch naar verifieerbare informatie zoeken om producten te categoriseren. In geval van bekende voedingstechnologieën gebruiken mensen niet-verifieerbare categorisatie criteria die automatisch vanuit het geheugen toegepast worden om producten te categoriseren.

Daarnaast bieden hoofdstuk 2 en 3 inzicht in hoe evaluaties van nieuwe voedingstechnologieën evolueren door de tijd heen. Het kan namelijk verondersteld worden dat meer automatische evaluatiestrategieën worden toegepast (en daardoor meer gebruik van niet-verifieerbare informatie) naarmate voedingstechnologieën bekender worden bij de consument.

In hoofdstuk 3 lieten we zien dat consumenten verschillende verwerkingsstrategieën (analytisch versus automatisch) toepassen wanneer ze voedingsproducten categoriseren. In hoofdstuk 4 onderzochten we of verschillende evaluatiestrategieën (product gebaseerd of proces gebaseerd) gebruikt worden wanneer consumenten voedingstechnologieën evalueren. Er vanuit gaande dat een product gebaseerde evaluatiestrategie een analytisch proces is, kan gesuggereerd worden dat deze strategie voornamelijk gebruikt wordt 
wanneer het een relatief niet bekende voedingstechnologie betreft. Aan de andere kant kan gesuggereerd worden dat een product gebaseerde evaluatiestrategie voornamelijk gebruikt wordt wanneer het een relatief bekende voedingstechnologie betreft. In hoofdstuk 4 werd aan honderdveertien consumenten gevraagd om genetisch gemodificeerde en biologische voedingsproducten te evalueren in combinatie met productievoordelen (bijvoorbeeld om het product lekkerder te laten smaken). We voorspelden dat de voordelen vooral van invloed zouden zijn op de evaluatie van een product wanneer het een relatief onbekend voedingsproduct betreft (product gebaseerde evaluatie). Aan de andere kant werd voorspeld dat voordelen niet meegenomen zouden worden in de evaluatie wanneer het een bekend voedingsproduct betreft (proces gebaseerde evaluatie). Hoofdstuk 4 liet zien dat de evaluatie van voedingsproducten productspecifiek is. Voordelen werden namelijk alleen maar meegenomen in de evaluatie van producten wanneer het relatief onbekende voedingsproducten betrof (genetisch gemodificeerde voeding). Wanneer het een bekend voedingsproduct betrof (biologische voeding), dan hadden de voordelen geen invloed op de evaluatie van dat product. Hoofdstuk 4 gaf verder inzicht in de relatie tussen het gebruik van verschillende evaluatiestrategieën (proces gebaseerd versus product gebaseerd) en attitudesterkte. Hoofdstuk 2 en 4 lieten zien dat consumenten een relatief sterke attitude hebben ten opzichte van relatief bekende voedingstechnologieën (zoals biologische productie) en een relatief zwakke attitude hebben ten opzichte van relatief onbekende voedingstechnologieën (zoals genetische modificatie). De resultaten van hoofdstuk 4 suggereerden dat product gebaseerde evaluatiestrategieën worden gebruikt wanneer attitudes van consumenten zwak zijn (genetische modificatie) en proces gebaseerde evaluatie strategieën wanneer het technologieën betreft waar consumenten een sterke attitude over hebben (biologische productie). Helaas lieten de resultaten van hoofdstuk 4 niet zien dat verschillende evaluatiestrategieën gebruikt worden wanneer consumenten binnen een technologie verschillen in attitudesterkte. Ook al kan alleen maar voorzichtig verondersteld worden dat interpersoonlijke verschillen in attitudesterkte het gebruik van verschillende evaluatiestrategieën (analytisch/product gebaseerd versus automatisch/proces gebaseerd) kan verklaren, kan gesuggereerd worden dat de evaluatie van nieuwe voedingstechnologieën productspecifiek is.

In hoofdstuk 4 werd gesuggereerd dat de evaluatie van voedingsproducten productspecifiek is. In hoofdstuk 5 werd onderzocht of de evaluatie van voedingsproducten productspecifiek is door te laten zien dat de evaluatie en acceptatie van voedingsproducten afhankelijk is van productkenmerken zoals of het product genetisch gemodificeerd is of niet en of het product bewerkt is of niet. In een pilot studie werd aan zesendertig studenten gevraagd om drie voedingsproducten te evalueren die een bekende bewerkte vorm hebben (bijvoorbeeld chips) naast hun onbewerkte vorm (bijvoorbeeld aardappelen). Daarnaast werd aan de respondenten gevraagd om deze producten te evalueren in genetisch gemodificeerde bewerkte en onbewerkte vorm (bijvoorbeeld genetisch gemodificeerde chips en genetisch gemodificeerde aardappelen). We voorspelden dat of een product genetisch gemodificeerd is of niet en of het een bewerkt product betreft of niet beide belangrijke kenmerken zijn die de evaluatie en acceptatie van de betreffende producten beïnvloeden. De pilotstudie liet zien dat deze twee kenmerken inderdaad twee belangrijke kenmerken zijn die de evaluatie en acceptatie van producten beïnvloeden. Meer specifiek is de mate waarin de evaluatie en de acceptatie van een product beïnvloed wordt door genetische modificatie dan wel door bewerktheid afhankelijk van of het product al eerder beïnloed is door bewerktheid of door genetische modificatie. Zo wordt de evaluatie en 
acceptatie van niet genetisch gemodificeerde producten die bewerkt worden en van niet bewerkte producten die genetisch gemodificeerd worden meer beïnvloed dan wanneer het producten betreft die al eerder beïnvloed waren door bewerktheid of door genetische modificatie (bijvoorbeeld genetisch gemodificeerde producten die bewerkt worden of bewerkte producten die genetisch gemodificeerd worden). Daarnaast werd in hoofdstuk 5 onderzocht of bepaalde niet-verifieerbare productattributen (waargenomen natuurlijkheid, gezondheid, noodzakelijkheid en smakelijkheid) van invloed waren op de relatie tussen de twee kenmerken (genetische modificatie en bewerktheid) en de acceptatie van voedingsproducten. De resultaten lieten zien dat de relatie tussen de twee kenmerken en de acceptatie van voedingsproducten door de niet-verifieerbare evaluatieattributen gemedieerd werd. De niet-verifieerbare evaluatieattributen bleken de acceptatie van producten die eenmalig veranderd waren (wanneer niet genetisch gemodificeerde producten bewerkt werden of wanneer niet bewerkte producten genetisch gemodificeerd werden) grotendeels te mediëren. Aan de andere kant bleken deze niet-verifieerbare evaluatieattributen de acceptatie van producten die twee keer veranderd waren (wanneer genetisch gemodificeerde producten bewerkt werden of wanneer bewerkte producten genetisch gemodificeerd werden) minder sterk te mediëren.

Er kan geconcludeerd worden dat hoofdstukken 4 en 5 suggereren dat de acceptatie van voedingstechnologieën productspecifiek is. De resultaten suggereren dat verscheidene productkenmerken (zoals of het product genetisch gemodificeerd is, of het product bewerkt is en of er voordelen genoemd worden) de evaluatie en acceptatie van voedingsproducten beïnvloeden. Deze resultaten bieden inzicht voor overheidsinstellingen en bedrijven over welke voedingsproducten het meest geaccepteerd worden door consumenten.

Samenvattend biedt het onderzoek dat in dit proefschrift gepresenteerd is inzicht in het mechanisme onderliggend aan de reacties van consumenten ten opzichte van innovatieve voeding. Niet alleen helpt dit inzicht om beter te begrijpen hoe voedingsproducten gepercipieerd en geëvalueerd worden, maar het kan ook de ontwikkeling van consumentevaluaties door de tijd heen beter voorspellen en het toekomstige succes. 
Reference List 


\section{A}

Armitage, C., \& Conner, M. (2000), Attitudinal ambivalence: A test of three key hypotheses. Personality and Social Psychology Bulletin, 26, 1421-1432.

\section{B}

Baron, R. M., \& Kenny, D. A. (1986). The moderator-mediator variable distinction in social psychological research: Conceptual, strategic, and statistical considerations. Journal of Personality and Social Psychology, 51, 1173-1182.

Bech-Larsen, T., \& Nielsen, N. A. (1999), A comparison of five elicitation techniques for elicitation of attributes of low involvement products. Journal of Economic Pychology, 20, 315-341.

Bosson, J. K., Swann, W. B., \& Pennebaker, J. (2000). "Stalking the perfect measures of implicit self-esteem: The blind man and the elephant revised?", Journal of Personality and Social Psychology, 79, 631-643.

Bredahl, L. (2001). Determinants of consumer attitudes and purchase intentions with regard to genetically modified foods: Results of a cross-national survey. Journal of Consumer Policy, 24, 23-61.

Burton, M., \& Pearse, D. (2003). Consumer attitudes towards genetic modification, functional foods, and microorganisms: A choice modeling experiment for beer. AgBioForum, 3, 14-19.

\section{C}

Conko, G. (2003, march 23). "Mandatory labeling is a bad idea". Objective Science.

Retrieved December 17, 2005, from http://www.objectivescience.com/articles/gc_labelfood.htm.

Costa, A. I. A., \& Jongen, W. M. F. (2006). New insights into consumer-led food product development. Trends in Food Science \& Technology, 17, 457-465.

Cox, D. N., Evans, G., \& Lease, H. J. (2007). The influence of information and beliefs about technology on the acceptance of novel food technologies: A conjoint study of farmed prawn concepts. Food Quality and Preferenece, 18, 306-314.

Cox, D. N., Evans, G., \& Lease, H. J. (2008). Australian consumers' preferences for conventional and novel sources of long chain omega-3 fatty acids: A conjoint study. Food Quality and preference, 19, 306-314.

Cuite, C. L., Aquino, H. L., \& Hallman, W. K. (2005). 'An empirical investigation of the role of knowledge in public opinion about GM food', International Journal of Biotechnology, 7, 178-194.

D

Daelemans, W., Gazdar, G., \& de Smedt, K. (1992). "Inheritance in natural language". Computational Linguistics, 18, 205-218.

De Barcellos, M. D., Kügler, J. O., Grunert, K. G., van Wezemael, L., Pérez-Cueto, F. J. A., Ueland, Ø., \& Verbeke, W. (2010). European consumers'acceptance of beef processing technologies: A focus group study. Innovative Food Science \& Emerging Technologies, 11, 721-732.

De Houwer, J. (2001). "A structural and process analysis of the Implicit Association Test", Journal of Experimental Social Psychology, 37, 443-451.

De Houwer, J. (2003). "The Extrinsic Affective Simon Task", Experimental Psychology, $50,77-85$. 
Dreezens, E. (2006). The missing link: The relationship between values and attitudes. PhD dissertation. Universiteit Maastricht, the Netherlands.

Dreezens, E., Martijn, C., Tenbült, P., Kok, G., \& De Vries, N.K. (2005). Food and the relation between values and attitude characteristics. Appetite, 45, 40-46.

\section{$\mathbf{E}$}

Eagly, A. H., \& Chaiken, S. (1993). The Psychology of Attitudes, Forth Worth, Texas: Harcourt Brace Janovich.

Epstein, S., \& Pacini, R. (2001). "The influence of visualization on intuitive and analytical information processing”. Imagination, Cognition, and Personality, 20, 195-216.

Eurobarometer. (2000, march 15). "The Europeans and biotechnology" (52.1). Brussels.

European consumers'acceptance of beef processing technologies: A focus group study. Innovative Food Science \& Emerging Technologies, 11, 721-732.

$\mathbf{F}$

Fazio, R. H., \& Olson, M. A. (2003). "Implicit measures in social cognitive research: Their meaning and use", Annual Review of Psychology, 54, 297-327.

Fischer, A. R. H., \& Frewer, L. J. (2009). Consumer familiarity with foods and the perception of risks and benefits. Food Quality and Preference, 20, 576-585.

Frewer, L.J., Howard, C., \& Shepherd, R. (1996). The influence of realistic product exposure on attitudes towards genetic engineering of food. Food Quality and Preference, 7, 61-67.

Frewer, L. J., Howard, C., \& Shepherd, R. (1998). The influence of initial attitudes on responses to communication about genetic engineering in food production. Agriculture and Human Values, 15, 15-30.

Fuller, G. W. (2004). New food product development: from concept to marketplace $\left(2^{\text {nd }}\right.$ ed.). CRC Press LLC.

G

Gamble, J., Muggleston, S., Hedderley, D., Parminter, T., \& Vaughan, G. (2000). Genetic engineering: The public's point of view. HortResearch NZ Client Report No. 2000/249. New Zealand: HortResearch NZ.

Garcia-Marques, T., \& Mackie, D. M. (2001). "The feeling of familiarity as a regulator of persuasive processing”. Social Cognition, 19, 9-34.

Gellynck, X, Vermeire, B., \& Viaene (2007). Innovation in food firms: Contribution of regional networks within the international business context. Entrepreneurship \& Regional Development, 19, 209-226.

Greenwald, A. G., McGhee, D. E., \& Schwartz, J. L. K. (1998). "Measuring individual differences in implicit cognition: The implicit association test", Journal of Personality and Social Psychology, 74, 1464-1480.

Grunert, K. G., Bredahl, L., \& Scholderer, J. (2003). "Four questions on European consumers' attitudes toward the use of genetic modification in food production". Innovative Food Science and Emerging Technologies, 4, 435-445.

Grunert, K. G., \& Valli, C. (2001). Designermade meat and dairy products: Consumer-led product development. Livestock Production Science, 72, 83-98.

\section{$\mathbf{H}$}

Hermans, D., Baeyens, F., \& Eelen, P. (2003). On the acquisition and activation of evaluative information in memory. The study of evaluative learning and affective priming combined. In J. Musch, \& D. C. klauer (Eds.), The psychology of evaluation: Affective processes in cognition and emotion. New Jersey: Laurence Erlbaum. 
Hoek, A. C., van Boekel, M. A. J. S., Voordouw, J., \& Luning, P. A. (2011). Identification of new food alternatives: How do consumers categorize meat and meat substitutes? Food Quality and Preference, 22, 371-383.

Hoffman, W., Gawronski, B., Gschwendner, T., Le, H., \& Schmitt, M. (2005). "A metaanalysis on the correlation between the implicit association test and explicit self-report measures", Personality and Social Psychology Bulletin, 31, 1369 - 1385.

Holland, R. (2003). On the structures and consequences of attitude strength. $\mathrm{PhD}$ dissertation. Radboud University Nijmegen, the Netherlands.

Holland, R. W., Verplanken, B., \& Van Knippenberg, A. (2002). "On the nature of attitudebehavior relation: The strong guide, the weak follow", European Journal of Social Psychology, 32, 869-876.

Hossain, F., Onyango, B., Adelaja, A., Schilling, B., \& Hallman, W. (2002). Consumer acceptance of food biotechnology: Willingness to buy genetically modified food products. Food Policy Institute Report No. WP-0602-001, Rutgers University.

House, L., Lusk, J., Jaeger, S., Traill, W. B., Moore, M., Valli, C., Morrow, B., \& Yee, W. M. S. (2004). "Objective and subjective knowledge: Impacts on consumer demand for Genetically Modified foods in the United States and the European Union", AgBioForum, 7, 113-123.

\section{$\mathbf{J}$}

Janiszewski, C., \& van Osselaar, S. M. J. (2000). "A connectionist model of brand-quality associations". Journal of Marketing Research, 37, 331-350.

Judd, C. M., Kenny, D. A., \& McClelland, G. H. (2001). Estimating and testing mediation and moderation in within-subject designs. Psychological Methods, 6, 115-134.

$\mathbf{K}$

Kaye-Blake, W., Bicknell, K., \& Saunders, S. (2005). Process versus product: Which determines consumer demand for genetically modified apples? The Australian Journal of Agricultural and Resource Economics, 49, 413-427.

Kunda, Z. (1999). Social Cognition: Making sense of people. MIT Press: Cambridge, Massachusetts.

$\mathbf{M}$

MacFie, H. (2007). Consumer-led food product development. Woodhead, Cambridge, UK.

Mackinnon, D. P., Lockwood, C. M., Hoffman, J. M., West, S. G., \& Sheets, V. (2002). A comparison of methods to test mediation and other intervening variable effects. Psychological methods, 7, 83-104.

MAPP annual report 2000. There is no accounting for tastes! Product advantages and tasting reduce consumers' scepticism towards genetically modified foods. Retrieved April 6, 2006, from http://crossenz.vtt.fi/mapp\%20annual\%20report\%202000consumerissues.pdf

McEachern, M. G., \& Willock, J. (2004). Producers and consumers of organic meat: A focus on attitudes and motivations. British Food Journal, 106, 534-552.

Miles, S., Ueland, O., \& Frewer, L. J. (2005). Public attitudes towards genetically-modified food. British Food Journal, 107, 246-262.

\section{$\mathbf{N}$}

Nayga, R. M., Aiew, W., \& Nichols, J. P. (2005). Information effects on consumers' willingness to purchase irradiated food products. Review of Agricultural Economics, $27,37-48$. 
Nielsen, H. B., Sonne, A. M., Grunert, K. G., Banati, D., Póllak-Tóth, A., Lakner, Z., Olsen, N. V., Zontar, T. P., \& Peterman, M. (2009). Consumer perception of the use of high-pressure processing and pulsed electric field technologies in food production. Appetite 52, 115-126.

Niemann, H., Sagerer, g. F., Schroder, S., \& Kummert, F. (1990). "ERNEST: A semantic network system for pattern understanding". IEEE Transactions on pattern analysis and machine intelligence, 12, 883-905.

Noussair, C., Robin, S., \& Ruffieux, B. (2004). Do consumers really refuse to buy

$\mathbf{O}$ genetically modified food? The Economic Journal, 114, 102-120.

Onyango, B., \& Nayga, Jr., R. M. (2004). Consumer acceptance of nutritionally enhanced genetically modified food. Journal of Agricultural and Resource Economics, 29, 567583.

Ottaway, S. A., Hayden, D. C., \& Oakes, M. A. (2001). "Implicit attitudes and racism: Effects of word familiarity and frequency in the Implicit Association Test", Social

$\mathbf{P}$ Cognition, 19, 97-144.

Perugini, M. (2005). Predictive models of implicit and explicit attitudes. British Journal of Social Psychology, 44 (1), 29-45.

Pew Initiative on Food and Biotechnology (2003). Survey Results: An Update on Public Sentiment About Agricultural Biotechnology. The Mellman Group, Inc., Washingon, DC.

$\mathbf{R}$

Rodriguez, L. (2007). The impact of risk communication on the acceptance of irradiated food. Science Communication 28, 476-500.

Roefs, A., Huijding, J., Smulders, F. T. Y., MacLeod, C. M., de Jong, P., Wiers, R. W., \& Jansen, A. (2011). Implicit measures of association in psychopathology research. Psychological Bulletin, 137, 149-193.

Rollin, F. R., Kennedy, J., \& Wills, J. (2011) Consumers and new food technologies. Trends in Food Science \& Technology 22, 99-111.

Rosch, E., Mervis, C. B., Gray, W. D., Johnson, D. M., \& Boyes-Braem, P. (1976). "Basic objects in natural categories". Cognitive Psychology, 8, 382-439.

Rozin, P., Spranca, M., Krieger, Z., Neuhaus, R., Surillo, D., Swerdlin, A., \& Wood, K. (2004). Preference for natural: instrumental and ideational/moral motivations, and the constrast between foods and medicines. Appetite, 43, 147-154.

\section{$\mathbf{S}$}

Saba, A., \& Vassallo, M. (2002). Consumer attitudes toward the use of gene technology in tomato production. Food Quality and Preference, 13, 13-21.

Sia, T. L., Lord, C. G., Blessum, K. A., Thomas, J. C., \& Lepper, M. R. (1999). “Activation of exemplars in the process of assessing social category attitudes". Journal of Personality and Social Psychology, 76, 517-532.

Siegrist, M., Stampli, N., Kastenholz, H., \& Keller, C. (2008). Perceived risks and perceived benefits of different nanotechnology foods and nanotechnology food packaging. Appetite, 51, 283-290.

Spence, A., Townsend, E. (2006). "Implicit attitudes towards genetically modified (GM) foods: A comparison of context-free and context-dependent evaluations", Appetite, 46, $67-74$ 
Steenkamp, J-B. E. M. (1989). Product quality: An investigation into the concept and how it is perceived by consumers. Assen: Van Gorcum.

Sternberg, R. J. (1996). Cognitive Psychology. Orlando, FL: Harcourt Brace College Publishers.

\section{$\mathbf{T}$}

Teisl, M. F., Fein, S. B., \& Levy, A. S. (2009) Information effects on consumer attitudes toward three food technologies: Organic production, biotechnology, and irradiation. Food Quality and Preference, 20, 586-596.

Tenbült, P., De Vries, N.K., Dreezens, E., \& Martijn, C. (2005). Perceived naturalness and acceptance of genetically modified food. Appetite, 45, 47-50.

Tenbült, P., De Vries, N.K., Dreezens, E., \& Martijn, C. (2007). Categorizing genetically modified food products: Effects of labelling on information processing. British Food Journal, 109, 305-314.

Tenbült, P., De Vries, N. K., Dreezens, E., \& Martijn, C. (2008). Intuitive and explicit reactions towards "new" food technologies: Attitude strength and familiarity. British Food Journal, 110, 622-635.

Tenbült, P., De Vries, N.K., Van Breukelen, G., Dreezens, E., \& Martijn, C. (2008). Acceptance of genetically modified foods: The relation between technology and evaluation. Appetite, 51, 129-136.

Traill, B. and Grunert, K. G. (1997). Product and process innovation in the food industry ( $1^{\text {st }}$ ed.). Chapman \& Hall.

Tuorila, H., Lahteenmaki, L., Pohjalainen, L., \& Lotti, L. (2001). Food neophobia among the Finns and related responses to familiar and unfamiliar foods. Food quality and preferences, 12, 29-37. 
Dankwoord 
Van Leonardo da Vinci wordt gezegd dat hij aan veel dingen is begonnen maar ze niet heeft afgemaakt. Als inspirator heeft hij voor anderen veel kunnen betekenen, maar met dat als resultaat heeft hij zelf geen vrede kunnen hebben. Op zijn sterfbed heeft hij zelfs vol wroeging en vol schuldgevoel zijn spijt betuigd aan God en de mensen omdat hij zoveel ongedaan had gelaten. De lering die hieruit getrokken kan worden is dat je dingen moet afmaken, wil je van je eigen meesterschap profijt hebben. Waarschijnlijk ben ik inderdaad meer een initiator dan een afmaker en of het inspirerend is voor anderen mag ik alleen maar hopen... Des te blijer en trotser ben ik dat ik toch niet lijd aan dat vermeende Leonardo da Vinci syndroom, waar ik overigens zelf nooit aan getwijfeld heb. Het bewijs daarvan ligt op dit moment voor jullie.

Ik wil graag wat mensen bedanken die de afgelopen jaren belangrijk voor mij zijn geweest, niet alleen in de realisatie van dit proefschrift, maar ook op andere vlakken in mijn leven. Ten eerste wil ik natuurlijk mijn promotor Nanne de Vries bedanken voor zijn geduld, advies en hulp die hij mij gegeven heeft. Met name wil ik hem bedanken voor de 'carte blanche' die hij mij gegeven heeft om zelf mijn ideeën voor mijn experimenten te laten bedenken. Ook al is het onderzoek van de hak op de tak gegaan en was het lastig om er een geheel (lees: proefschrift) van te maken, het is toch een manier die bij mij past en die ik niet anders had willen doen! Daarnaast wil ik jou, Nanne, bedanken voor de man die je bent. Altijd kon ik bij je terecht met mijn persoonlijke perikelen en altijd luisterde je naar mij en stond je me bij met raad en daad. Dit heb ik altijd als enorm prettig ervaren. Daarnaast wil ik natuurlijk ook mijn copromoter Carolien Martijn bedanken. Jij was mijn springplank naar de wetenschap. In mijn laatste studie jaar hebben jouw vakken mij laten inzien dat mijn affiniteit uitgaat naar sociaal cognitieve psychologie en dat ik binnen dit gebied verder wilde. Ik weet nog goed toen ik voor de eerste keer aan je deur stond om te vragen of je een stage opdracht voor me had. Ik had toen niet durven dromen dat dat betreffende onderzoek later internationaal gepubliceerd zou worden en dat ik vervolgens als promovendus aan de slag kon gaan. Carolien, bedankt voor de kans die je mij gegeven hebt om nu te kunnen doen wat ik zo graag doe! Daarnaast wil ik Gerard van Breukelen bedanken. Gerard, ik heb ontzettend veel van je geleerd en ik vind het nog steeds geweldig dat ik jouw naam op één van mijn publicaties mocht zetten. Je hebt me geïnspireerd, ontzettend bedankt daarvoor! Ten slotte wil ik wat betreft de Universiteit Maastricht al mijn collega's van de vakgroep Gezondheidsbevordering bedanken. Graag wil ik van de gelegenheid gebruik maken om een paar mensen expliciet te noemen, namelijk Gert-Jan, Leon, Marit en Roos. Jullie waren voor mij meer dan collega's! Bedankt voor de openhartige gesprekken, de gezellige etentjes en de steun wanneer ik die nodig had. Als laatste wil ik Marja bedanken. Ik kan me niet voorstellen dat er iemand bestaat die niet zal beamen dat je van onschatbare waarde bent voor 'onze' capaciteitsgroep. Bedankt voor het voorbeeld dat je bent, je vertrouwen, je gesprekken en alles wat je gedaan hebt om mijn promotie mogelijk te maken!

Ik wil ook mijn collega's van het departement Marketing Management van Tilburg University bedanken die mij met open armen ontvangen hebben en die altijd geïnteresseerd zijn geweest in zowel mijn proefschrift als in mij als persoon. Ik vind het enorm fijn dat we zo open naar elkaar kunnen zijn! Met name wil ik Peter bedanken. Jij bent niet alleen jaren lang mijn 'roomie' geweest, maar ook mijn klankbord, schouder, rots en maatje. Jij ziet wat er in mij om gaat en je kent mij beter dan ik mezelf ken.

En dan wil ik natuurlijk mijn twee paranimfen bedanken: Ellen en Boukje. Ellen, jij hoort eigenlijk in meerdere rijtjes thuis die ik hierboven beschreven heb. We hebben samen 
onze studie- en aiotijd in Maastricht doorlopen en nu ben je mijn collega in Tilburg. Je bent een enorm fijne meid waarmee ik naar vele cursussen en symposia in binnen- en buitenland ben gegaan. De afgelopen jaren zijn daar ook nog eens een aantal mooie studie reizen van ASSET Marketing bij gekomen. Bedankt voor de mooie momenten, je eigen zinnigheid, je luisterend oor, je geduld en je spiegel ;)! Bouk, jij bent bijzonder belangrijk voor me geweest tijdens mijn studietijd. Ik wil je bedanken voor de vele leuke en goede gesprekken die we gehad hebben in ons studentenhuis op de Demertstraat, het indoor sneeuwballen gevecht aldaar, de overdaad aan donsdek op de Welsdaal en het stappen in de zuidelijkste provincie van Nederland. Ik heb mede dank zij jou een supertijd in Maastricht gehad! Helaas zien we elkaar niet meer zo veel maar weet dat ik je enorm waardeer en er trots op ben dat je samen met jouw baby in je buik helemaal uit Hamburg bent gekomen om mij bij te staan als paranimf.

Ik wil ook graag mijn vrienden bedanken. Ik mag me zelf enorm gelukkig prijzen met vrienden zoals jullie! Een aantal mensen verdient het om bij naam genoemd te worden: Amunda en Ivo, Anke, Anneke, Arianne, Bas, Bob, Carlijn, Cindy en Erwin, Eveline en Kevin, Ferry, Gerrie, Hanneke, Karina, Monique, Natascha, Stephan, Renske, Rianne, Rick en de families Ausems, Brom, Foudraine en Hoekstra. Bedankt dat jullie er altijd voor mij zijn. Jullie weten wat dit proefschrift voor mij betekent en ik weet dat jullie oprecht trots op mij zijn! In het bijzonder wil ik Vincent bedanken. Er is niemand op de wereld die zo goed weet hoeveel werk en hoeveel offers het gekost heeft om dit proefschrift en mijn publicaties te schrijven. Vincent, bedankt dat je er al die jaren voor mij geweest bent!

Ten slotte wil ik graag mijn familie bedanken. Pap, mam, bedankt dat jullie mij altijd mijn gang hebben laten gaan en altijd achter mijn keuzes hebben gestaan. Erik en Suzan, Bart en Karin, Walter en natuurlijk mijn twee schatjes: Sterre en Milan. Wat ben ik blij en trots dat ik jullie tante Peteráá ben!

In de afrondingsfase van dit proefschrift zijn er nog twee mensen in mijn leven bij gekomen, Sébastiaan en kleine Emma. Ik hoop dat wij meer mogen initiëren en elkaar langer mogen inspireren dan dit proefschrift ooit zal kunnen doen $: ;$ ! 
Curriculum Vitae 
Petra Tenbült werd op 17 november 1977 te Hoogeloon geboren. Ze haalde in 1997 haar VWO diploma aan het Pius-x College te Bladel. In dat zelfde jaar begon ze aan haar studie Psychologie aan de Universiteit Maastricht. In 2001 behaalde ze daar haar doctoraal diploma met als afstudeerrichting Onderwijs Psychologie. Van 2001 tot mei 2006 was ze vervolgens werkzaam als Assistent in Opleiding bij de capaciteitsgroep Gezondheidsbevordering van Universiteit Maastricht. Het resterende jaar werkte ze bij Masterfoods te Veghel als 'Consumer Insight's scientist' op de afdeling research and development. Sinds 2007 is ze werkzaam als docent op het departement Marketing Management van Tilburg University. 
The "Kurt Lewin Institute Dissertation Series" started in 1997. Since 2009 the following dissertations have been published:

2009-1: $\quad$ Marijke Leliveld: Ethics in Economic Decision-Making

2009-2: Monique Pollmann: Accuracy and Bias in Person Perception

2009-3: $\quad$ Krispijn Faddegon: Regulatory Focus in Group Contexts

2009-4: $\quad$ Lieven Brebels: Mirror, mirror on the wall... Procedural fairness as anevaluative and regulatory looking-glass self

2009-5: $\quad$ Daphne Wiersema: Taking it personally: Self-esteem and the protection of selfrelated attitudes

2009-6: Judith D.M. Grob: Dial E for Emotion: Context and Consequences of Emotion Regulation

2009-7: Katherine Stroebe: Is this about me? Responding to subtle discrimination beyond an individual versus group perspective

2009-8: $\quad$ Menno Vos: Identity patterns in diverse work groups: Improving social integration outcomes through relational identities

2009-9: $\quad$ Lennart Renkema: Facing Death Together: Understanding The Consequences of Mortality Threats

2009-10: Michael Vliek: Group-based social comparison processes: An intragroup level of analysis

2009-11: Karlijn Massar: Unconscious rivals: The automatic evaluation of rivals in jealousy-evoking situations

2009-12: Bart Terwel: Origins and consequences of public trust: Towards an understanding of public acceptance of carbon dioxide capture and storage

2009-13: Emma ter Mors: Dealing with information about complex issues: The role of source perceptions

2009-14: Martijn Veltkamp: On the Instigation of Implicit Motivation: How Deprivation and Positive Affect Cause Motivated Behavior

2009-15: Marret K. Noordewier: Consistency and the unexpected

2009-16: Sytske van der Velde: Imitation of Emotion: How meaning affects the link between imitation and liking

2009-17: Jacomijn Hofstra: Attaching Cultures: The role of attachment styles in explaining majority members' acculturation attitudes

2009-18: Jacqueline Tanghe: Affect in Groups: Convergence, Conditions and Consequences

2009-19: Anne Marike Lokhorst: Using Commitment to Improve Environmental Quality

2009-20: Jonathan van 't Riet: Framing Health Communication Messages

2009-21: Suzanne Pietersma: Persuasive Health Communication: A Self-Perspective

2009-22: Remco Wijn: A functional perspective on the justice judgment process and its consequences

2009-23: Niels van de Ven: The bright side of a deadly sin: The psychology of envy

2009-24: Anthon Klapwijk: The Power of Interpersonal Generosity

2010-1: $\quad$ Maarten Wubben: Social Functions of Emotions in Social Dilemmas

2010-2: Joyce Rupert: Diversity faultlines and team learning

2010-3: $\quad$ Daniel Lakens: Abstract Concepts in Grounded Cognition

2010-4: $\quad$ Luuk Albers: Double You? Function and Form of Implicit and Explicit SelfEsteem

2010-5: Matthijs Baas: The Psychology of Creativity: Moods, Minds, and Motives 
2010-6: $\quad$ Elanor Kamans: When the Weak Hit back: Studies on the Role of Power in Intergroup Conflict

2010-7: $\quad$ Skyler Hawk: Changing Channels: Flexibility in Empathic Emotion Processes

2010-8: $\quad$ Nailah Ayub: National Diversity and Conflict: The Role of Social Attitudes and Beliefs

2010-9: Job van der Schalk: Echoing Emotions: Reactions to Emotional Displays in Intergroup Context

2010-10: Nevra Cem: Organizational citizenship behavior and counterproductive work behavior: Cross-cultural comparisons between Turkey and the Netherlands

2010-11: Ron Broeders: On Situated and Embodied Knowledge Regarding Moral Issues

2010-12: Margriet Braun: Dealing with a deviant group member

2010-13: Dennis Bleeker: Representing or defecting? The pursuit of individual upward mobility in low status groups

2010-14: Petra Hopman: Group Members Reflecting on Intergroup Relations

2010-15: Janneke Oostrom: New Technology in Personnel Selection: The Validity and Acceptability of Multimedia Tests

2010-16: Annefloor Klep: The Sharing of Affect: Pathways, Processes, and Performance

2010-17: Geertje Schuitema: Priceless policies. Factors influencing the acceptability of transport pricing policies

2010-18: Femke van Horen: Breaking the mould on copycats: What makes product imitation strategies successful?

2010-19: Niek van Ulzen: Exploring affective perception and social action

2010-20: Simon Dalley: Women's body dissatisfaction and restrictive eating behaviour: A tyranny of a thin-ideal or a fear of fat?

2010-21: Paul Preenen: Challenge at Work: A matter of give and take

2010-22: Katarzyna Ewa Kubacka: The Rules of Attraction: Trust, Anxiety and Gratitude

2010-23: Loes Kessels: May I have your attention please? A neuroscientific study into message attention for health information

2011-1: $\quad$ Elze Ufkes: Neighbor-to-neighbor conflicts in multicultural neighborhoods

2011-2: Kim van Erp: When worlds collide. The role of justice, conflict and personality for expatriate couples' adjustment

2011-3: Yana Avramova: How the mind moods

2011-4: Jan Willem Bolderdijk: Buying people: The persuasive power of money

2011-5: Nina Regenberg: Sensible Moves

2011-6: Sonja Schinkel: Applicant reactions to selection events: Interactive effects of fairness, feedback and attributions

2011-7: $\quad$ Suzanne Oosterwijk: Moving the Mind: Embodied Emotion Concepts and their Consequences

2011-8: $\quad$ Ilona McNeill: Why We Choose, How We Choose, What We Choose: The Influence of Decision Initiation Motives on Decision Making

2011-9: $\quad$ Shaul Shalvi: Ethical Decision Making: On Balancing Right and Wrong

2011-10: Joel Vuolevi: Incomplete Information in Social Interactions

2011-11: Lukas Koning: An instrumental approach to deception in bargaining

2011-12: Petra Tenbült: Understanding consumers' attitudes toward novel food technologies 

